\title{
THE REPTILIAN OPTIC TECTUM
}

\author{
G. CARL HUBER AND ELIZABETH C. CROSBY \\ Laboratory of Comparative Neurology, Department of Anatomy, \\ University of Michigan \\ TWELVE PLATES \\ INTRODUCTION
}

Limited by available space, the following discussion of the gray matter and fiber connections of the optic tectum of Reptilia of necessity is restricted to an account of the more prominent structural features subservient to an understanding of the functional pattern. This has limited a consideration of juxtaposed fields and more particularly of the pretectal and diencephalic areas. These will be considered in a comprehensive treatment of the diencephalon now in process of preparation. The breadth of material used again calls attention to the value of having available for comparison and study the brains of closely related forms, cut in several planes and prepared so as to portray nuclear pattern and fiber connections of both myelinated and non-myelinated nerve fibers.

Here, may we be permitted to record our pleasure in giving expression of appreciation in this dedicatory volume.

\section{MATERIAL AND METHODS OF PREPARATION}

As may be observed from a study of the following table, listing the series of reptilian brains available for this investigation, a relatively large number of series were at our disposal, prepared after various methods and eut in several planes. For the sake of brevity, the table here compiled is condensed as much as is consistent with a clear understanding.

57

THE JOURAal OF COMPARATIVE NeURology, vol, 57 , No, 1 


\begin{tabular}{|c|c|c|c|c|c|c|}
\hline \multirow{2}{*}{ FORM } & \multirow{2}{*}{$\begin{array}{l}\text { PLANE OF } \\
\text { SEOTION }\end{array}$} & \multicolumn{4}{|c|}{ METHOD OF PREPARATION } & \multirow{2}{*}{$\begin{array}{l}\text { NUM- } \\
\text { BERS }\end{array}$} \\
\hline & & $\underset{\text { Toluidin }}{\text { blue }}$ & $\begin{array}{l}\text { Chrom. } \\
\text { silver }\end{array}$ & Weigert & Golgi & \\
\hline Turt?es: & & & & & & \\
\hline $\begin{array}{l}\text { Chelhydra serpentina (old) } \\
\text { Chelhydra serpentina } \\
\text { (just hatched) }\end{array}$ & $\begin{array}{l}\text { Cross } \\
\text { Cross } \\
\text { Sagittal } \\
\text { Frontal }\end{array}$ & $\begin{array}{l}3 \\
1 \\
0 \\
0\end{array}$ & $\begin{array}{l}1 \\
4 \\
1 \\
1\end{array}$ & $\begin{array}{l}0 \\
0 \\
0 \\
0\end{array}$ & $\begin{array}{l}0 \\
0 \\
0 \\
0\end{array}$ & \\
\hline Chrysemys marginata & $\begin{array}{l}\text { Cross } \\
\text { Sagittal } \\
\text { Frontal }\end{array}$ & $\begin{array}{l}1 \\
2 \\
1\end{array}$ & $\begin{array}{l}0 \\
0 \\
0\end{array}$ & $\begin{array}{l}0 \\
0 \\
0\end{array}$ & $\begin{array}{l}0 \\
0 \\
0\end{array}$ & \\
\hline Chrysemys punctata & $\begin{array}{l}\text { Cross } \\
\text { Sagittal } \\
\text { Frontal }\end{array}$ & $\begin{array}{l}1 \\
0 \\
0\end{array}$ & $\begin{array}{l}1 \\
3 \\
0\end{array}$ & $\begin{array}{l}1 \\
1 \\
1\end{array}$ & $\begin{array}{l}0 \\
0 \\
0\end{array}$ & \\
\hline Sternotherus odoratus & $\begin{array}{l}\text { Cross } \\
\text { SagittaI } \\
\text { Frontal }\end{array}$ & $\begin{array}{l}1 \\
1 \\
0\end{array}$ & $\begin{array}{l}1 \\
1 \\
0\end{array}$ & $\begin{array}{l}0 \\
0 \\
0\end{array}$ & $\begin{array}{l}0 \\
0 \\
0\end{array}$ & \\
\hline $\begin{array}{l}\text { Graptemys } \\
\text { pseudogeographica }\end{array}$ & Cross & 2 & 0 & 0 & 0 & \\
\hline Pseudoemys elegans & $\begin{array}{l}\text { Cross } \\
\text { Sagittal } \\
\text { Frontal }\end{array}$ & $\begin{array}{l}1 \\
1 \\
1\end{array}$ & $\begin{array}{l}0 \\
0 \\
0\end{array}$ & $\begin{array}{l}0 \\
0 \\
0\end{array}$ & $\begin{array}{l}1 \\
3 \\
0\end{array}$ & 33 \\
\hline $\begin{array}{l}\text { Lizards: } \\
\quad \text { Holbrookia }\end{array}$ & $\begin{array}{l}\text { Cross } \\
\text { Sagittal }\end{array}$ & $\begin{array}{l}1 \\
1\end{array}$ & $\begin{array}{l}0 \\
0\end{array}$ & $\begin{array}{l}0 \\
0\end{array}$ & $\begin{array}{l}0 \\
0\end{array}$ & \\
\hline Anolis Car. & $\begin{array}{l}\text { Cross } \\
\text { Sagittal } \\
\text { Frontal }\end{array}$ & $\begin{array}{l}1 \\
1 \\
1\end{array}$ & $\begin{array}{l}3 \\
2 \\
2\end{array}$ & $\begin{array}{l}0 \\
0 \\
0\end{array}$ & $\begin{array}{l}0 \\
0 \\
0\end{array}$ & \\
\hline Heloderma suspectum & $\begin{array}{l}\text { Cross } \\
\text { Sagittal } \\
\text { Frontal }\end{array}$ & $\begin{array}{l}2 \\
1 \\
1\end{array}$ & $\begin{array}{l}4 \\
3 \\
0\end{array}$ & $\begin{array}{l}1 \\
0 \\
0\end{array}$ & $\begin{array}{l}1 \\
0 \\
0\end{array}$ & \\
\hline Phrynosoma coronatum & $\begin{array}{l}\text { Cross } \\
\text { Sagittal } \\
\text { Frontal }\end{array}$ & $\begin{array}{l}1 \\
0 \\
1\end{array}$ & $\begin{array}{l}2 \\
1 \\
0\end{array}$ & $\begin{array}{l}0 \\
0 \\
0\end{array}$ & $\begin{array}{l}0 \\
0 \\
0\end{array}$ & \\
\hline Varanus griseus & Cross & 1 & $\mathbf{1}$ & 0 & 0 & 32 \\
\hline $\begin{array}{l}\text { Snakes: } \\
\text { Natrix }\end{array}$ & $\begin{array}{l}\text { Cross } \\
\text { Sagittal } \\
\text { Frontal }\end{array}$ & $\begin{array}{l}1 \\
1 \\
1\end{array}$ & $\begin{array}{l}1 \\
1 \\
1\end{array}$ & $\begin{array}{l}1 \\
0 \\
0\end{array}$ & $\begin{array}{l}0 \\
0 \\
0\end{array}$ & \\
\hline Thamnophis sirtalis & $\begin{array}{l}\text { Cross } \\
\text { Sagittal } \\
\text { Frontal }\end{array}$ & $\begin{array}{l}1 \\
1 \\
1\end{array}$ & $\begin{array}{l}0 \\
0 \\
0\end{array}$ & $\begin{array}{l}0 \\
0 \\
0\end{array}$ & $\begin{array}{l}0 \\
0 \\
0\end{array}$ & \\
\hline Boa constrictor (small) & $\begin{array}{l}\text { Cross } \\
\text { Sagittal } \\
\text { Froutal }\end{array}$ & $\begin{array}{l}0 \\
0 \\
0\end{array}$ & $\begin{array}{l}2 \\
1 \\
2\end{array}$ & $\begin{array}{l}0 \\
0 \\
0\end{array}$ & $\begin{array}{l}0 \\
0 \\
0\end{array}$ & \\
\hline Python molurus & $\begin{array}{l}\text { Cross } \\
\text { Sagittal }\end{array}$ & $\begin{array}{l}1 \\
1\end{array}$ & $\begin{array}{l}1 \\
0\end{array}$ & $\begin{array}{l}0 \\
0\end{array}$ & $\begin{array}{l}0 \\
0\end{array}$ & \\
\hline Agkistrodon mokasen & $\begin{array}{l}\text { Cross } \\
\text { Sagittal } \\
\text { Frontal }\end{array}$ & $\begin{array}{l}1 \\
0 \\
0\end{array}$ & $\begin{array}{l}1 \\
0 \\
1\end{array}$ & $\begin{array}{l}0 \\
0 \\
0\end{array}$ & $\begin{array}{l}0 \\
0 \\
0\end{array}$ & 21 \\
\hline Alligator mississippiensis & $\begin{array}{l}\text { Cross } \\
\text { Sagittal } \\
\text { Frontal }\end{array}$ & $\begin{array}{l}2 \\
2 \\
2\end{array}$ & $\begin{array}{l}5^{1} \\
2 \\
0\end{array}$ & $\begin{array}{l}1 \\
1 \\
0\end{array}$ & $\begin{array}{l}2^{3} \\
6^{2} \\
0\end{array}$ & 23 \\
\hline
\end{tabular}

Includes one series prepared in Prof. C. Judson Herrick's laboratory.

Incomplete series. 


\section{GENERAL RELATIONS OF THE OPTIC TECTUM}

The optic tectal or superior collicular region in reptiles has been recognized so generally that a detailed account of its position and gross relations is deemed unnecessary. However, there are present certain features that deserve emphasis. As has been stated previously (Ariëns Kappers, '20-'21; Shanklin, '30, and others) an inferior collicular eminence, ${ }^{1}$ demarked dorsally and ventrally by shallow sulci, occurs on the dorsocaudal surface of the tectum in lizards (fig. $1 \mathrm{~A}$ and B). Similar eminences, similarly demarked, are present in the snake material available for study (fig. 2 B). In lizards, such as Anolis and Phrynosoma, and in snakes, such as Natrix and Thamnophis, little or no ventricular eminences are produced by the inferior colliculi. In the musk turtle (Sternotherus odoratus), in Chelhydra and Chrysemys (fig. $2 \mathrm{~A}$ ) the inferior colliculi produce slight surface eminences, with attendant sulci and relatively prominent ventricular enlargements. In the young alligator brain (fig. $1 \mathrm{C}$ ) these large gray masses are rolled into the ventricle and do not extend to the surface, but there may be noted a slight elevation of the overlying white layer of the region which is demarked by indefinite sulci, homologous to the more pronounced swelling and more distinct sulci observed in other reptiles. The relations in the young alligator foreshadow those characteristic of avian forms.

A further feature to be emphasized relates to the fact that the inferior colliculus on each side is in intimate cellular and fiber relations with the stratum griseum periventriculare of the homolateral superior colliculus (figs. 1 and 2). In certain planes the rows of periventricular cells form a partial cap-

\footnotetext{
1 The writers are aware that the homology of the reptilian corpus posterius with the mammalian inferior colliculus is not established beyond question and that ultimately embryological as well as neurological data must be taken into consideration. In the absence of such data for reptiles, the general position and connections of the region, its intimate relations with the periventricular layers of the optic tectum suggest that it falls at least within the inferior collicular field of mammals even if it is not directly homologous with the inferior collicular nucleus of these latter forms. The term is used with just such a general implication in the present paper.
} 
sular layer about the inferior collicular nucleus, particularly around its medial border; other periventricular cells become continuous with inner gray, and the small fasciculi of fibers between the rows of cells break up into a rich plexus between the neurons. Overlying the inferior colliculus are efferent paths of the superior colliculus representing ventro-caudal continuations of the stratum album centrale of the latter area. This inferior collicular gray has the appearance of being a differentiated portion of the mesencephalic periventricular gray.

CELLULAR ARRANGEMENT AND STRUCTURE OF THE OPTIC TECTUM

Even a superficial examination of microseopic preparations of the midtectal region of lizard, less distinctly so of turtles and alligators, reveals a distinct lamination or layer arrangement characteristic of the region. A less distinct lamination is observed in snakes. The nerve cells and nerve fibers are found arranged in laminae or strata, concentrically disposed from ventricle to superficial surface. The distinctness and differentiation of the different strata vary in different reptiles, as recorded in this account, but for a given reptile the pattern is relatively constant throughout the tectal area and can be seen in appropriate sections cut either transversely or in the longitudinal plane (figs. 1 to 4 ).

In Emys Bellonci (1888) described eight layers within the optic tectum: 1) a ciliated epithelial layer;2) a medullated fiber layer; 3) a layer of small nerve cells non-stainable in osmic acid; 4) a layer of radially arranged nerve cells stainable in osmic acid; 5) a concentrically arranged medullated nerve fiber layer consisting of partly longitudinally and partly cross cut fibers; 6 ) a thick layer consisting of a fibrillar network with intermingled cells of the following typesa) darkly staining, multipolar cells; $b$ ) small spindle shaped, radially arranged, and deeply stainable cells; $c$ ) cells similar to $b$, but not deeply stained; 7) a layer of optic fibers; 8) a fibrillar network. 
An excellent account of the various layers or zones of the chameleon tectum, together with certain details of their cell forms, is to be found in the 1896 paper of Pedro Ramón. By reason of its importance to the present study, a brief summary will be given of certain pertinent results obtained by this observer.

Ramón recognized and described the following layers in the optic tectum:

1. An epithelial zone consisting of ependymal elements with processes radiating toward the surface of the tectum.

2. A molecular zone composed chiefly of dendritic processes from cells of the overlying zones ( 3 and 5 ), but containing also a few thin medullated nerve fibers and a certain number of scattered nerve cells.

3. A cellular zone composed of two or three rows of cells of three distinct types: a) a piriform or pyramidal type with basilar dendrites ramifying in the adjoining zones (2 and 4), apical dendrites extending toward the periphery and giving off side branches at the various cell levels and a neuraxis which enters the peripheral fiber zone, giving off collaterals in its course; $b$ ) a cell similar to that just described, except that its neuraxis is given off from a dendrite in the region of zone 9 , forms a distinct crook or arch and runs ventricleward until zone 6 is reached which it enters; $c$ ) a cell the neuraxis of which is given off at the bifurcation of the apical dendrite in layer 7, courses peripheralward for a short distance and then turns back to break up within zone 7 into a series of terminal branches.

4. A molecular zone containing a dendritic plexus and certain myelinated fibers.

5. A cellular zone composed of three to five cell layers separated by fiber bands. Cells of the three types described in zone 3 occur here.

6. A molecular zone formed chiefly of myelinated fibers. A small number of neurons are found here; of these the giant ganglion cells send out dendrites which spread widely in their course toward the periphery. Other cells found here and known as 'células empenachadas' or plumed cells have an elongated, more or less cylindric body from which numerous dendrites are given off. Occasionally such a dendritic branch runs horizontally giving off in its course oblique branches toward the periphery. These and the preceding cells also 
occur in zone 7. The fibers in zone 6 show various arrangements, being sagittally arranged in the inside of the layer, obliquely in the middle position and tangentially in the external and inferior portion. The layer delimits along its inner border relatively clearly, but along its outer border fascicles of fibers are given off which extend outward at least as far as the arborizations of the incoming optic nerve fibers. This layer contributes to the posterior commissure and at the more lateral portion of the layer two bundles of fibers are given off, an inner which forms a partial decussation under the floor of the fourth ventricle in the region of the oculomotor and an external portion which swings farther lateralward. Both bundles later assume a horizontal direction. Certain of the fibers of zone 6 appear to connect with the corpus inferior. Ramón found the following cells contributing axis cylinders to this layer: the 'células en cajado,' the large triangular cells, the conical or pyramidal cells of both the 8th and 9 th zones, and the so-called 'células empenachadas' or plumed cells of both the 6 th and 7 th zones.

7. A zone containing many irregularly distributed neurons. It was divided into three portions-a) a deep portion containing numerous cells of varying types, particularly the plumed cells (células empenachadas) and the células en cajado, which were found also in zone $6 ; b$ ) a middle strata consisting of irregular groups of cells many of them representing a special type of célula en cajado, which gives off a rich plexus toward the periphery. From such a dendritic branch arises a hooked neuraxis which runs ventricleward to enter the central fiber zone (zone 6), and, $c$ ) a peripheral zone containing scattered cells of several types and among these special type of 'célula en cajado' (described in zone 3 ) with a peripherally directed axis cylinder and a conical or fusiform type with a neuraxis extending ventralward toward the 6 th zone, while the dendrites extend into the formation of the peripheral plexuses.

8. A cellular zone, composed of 2 or 3 irregular rows of cells better differentiated in the lateral proximal region than in the medial region where they are more or less intermingled with the external layer of zone 7 . The peripherally directed dendrites of such cells ramify in the peripheral plexuses; the centrally directed dendrites in the 7 th zone. The neuraxes give off side branches in their course through the 7 th into the 6th zone. At the level of the 8th zone there may be observed fine irregularly oriented fascicles, which possibly 
belong, at least in part, to the fasciculus optico-commissuralis of Ramón (see p. 84).

9. A molecular zone which contains a few scattered cells and in which the deepest of the optic fibers arborize. There is present a rich dendritic plexus.

10. A narrow, irregular cellular zone containing two distinct cell types: a) a small cell with peripherally extending, richly branching dendrites and centrally directed neuraxis breaking up into many fine branches in the 7th zone, and $b$ ) a cell with horizontally arranged dendrites and a neuraxis running horizontally for some distance and appearing to turn centralward with destination uncertain.

11. A molecular zone characterized particularly by the presence of a very rich terminal arborization of optic fibers, the finer branches presenting varicosities. The cellular elements in this zone resemble those described for the preceding layer. However, one type of cells has a neuraxis which deserves special mention, since it divides, one branch passing peripheralward, while the other passes centralward.

12. A zone formed of an irregular row of small cells intercalated in the interstices of a plexus of medullated fibers, which are continuous with the optic tract. The cells are of two types: a) tangential cells similar to those described for zone 10, with neuraxes breaking up into terminal arborizations in the same zone and, $b$ ) neurons showing no definite orientation, with short, bent dendrites and a neuraxis which enters the interior of the tectum.

13. A molecular zone containing only a few scattered cells and optic tract fibers for which it constitutes the most peripheral region of termination. Into this region extend the terminations of the giant ganglion cells of the 6th zone. Irregularly arranged small cells and cells with horizontally coursing dendrites, such as were described in zone 12, occur in small numbers.

14. A zone of optic tract fibers and a considerable number of neuraxes ascending from deeper levels of the tectum. From here the optic fibers run obliquely away from the surface to end in their three levels of termination, namely, zones 13, 11, and probably also zone 7. Ramón's consideration of the richness of these terminations and its significance will be discussed with the consideration of the optic tract.

A brief account of the optic tectum of reptiles is to be found in the 1911 edition of Ramón y Cajal's text. This account and 
the figures are based on the description and figures of Pedro Ramón. Ramón y Cajal reiterated his brother's statement that a strong resemblance exists between the tectum of reptiles and birds.

In 1913 de Lange published a very brief account of the optic tectum of reptiles in which he followed the plan laid down by P. Ramón, with whom his results are in essential agreement. de Lange made use of material prepared after the methods of Golgi, Bielschowsky, Weigert, and Pal and series stained with cresylviolet. Lacerta agilis was the reptile particularly studied and figured. The most significant additions to the knowledge of the reptilian tectum made by de Lange are found in his accounts of the relations of certain of the fiber bundles to the various layers. His observations will receive consideration in the consideration of tectal connections. In their paper on certain diencephalic and tectal centers of the alligator brain, Huber and Crosby ('26) noted the presence of fourteen tectal layers as described for the lizard, as did Shanklin ('30) for Chameleon. Cairney ('26) described five layers in Sphenodon (see p. 65).

\section{Classification of the layers}

This brief presentation of the literature dealing with the morphology of the optic tectum evidences quite clearly that there exists a stratification readily determinable even on cursory examination of suitably prepared cell or fiber preparations. A study of extensive reptilian series embracing various types makes it evident that, while in all forms a layering comparable to that postulated in the literature can be made out, these layers are found to vary in distinctness and in relative emphasis along certain lines in conformity with a pattern which is fundamental for all reptilian types and comparable to that characteristic of lower mammals and even of mammals generally. The following revision of the classification of the laminae of the optic tectum in no sense postulates a lack of full appreciation of the significance of the earlier work. The problem involved in a consideration of 
the reptilian tectum is twofold. One necessary aspect of that problem is found in the high degree of specialization within this brain center. This finds morphologic expression in the stratification of the area, and to amplify this only minor details can be added to the results of the earlier fundamental work. The other aspect of the problem concerns the interpretation of this specialized structure with its variants in different types to a pattern which shall be common not only to reptiles, but a pattern which admits of ready homology with other vertebrate patterns of optic tectal structure. The reclassification of the laminae of the tectal centers presented in this account evidences an attempt to consider this second aspect of the problem of the reptilian tectal structure.

Exclusive of the ependyma there may be recognized six fundamental layers in the optic tectum of turtles, lizards, snakes, and alligators. The reasons for so dividing this area obviously cannot be given until all the available evidence has been presented, therefore the discussion of this evidence is placed at the end of this contribution. For greater ease of description of fiber connections, the layers listed are enumerated and considered beginning with the superficial surface of the tectum and proceeding to its deep surface. These layers are as follows:

1. Stratum opticum. A layer of optic tract fibers, comparable to zone 14 of Ramón, to the seventh layer of Bellonci and to the stratum opticum of mammals. It is the principal optic layer (a) of Cairney ('26).

2. Stratum fibrosum et griseum superficiale. A layer of alternating bands of gray and white, including zones 8 to 13 of Ramón, essentially the sixth layer of Bellonci and constituting an important region for the reception, correlation, and reinforcement of impulses.

3. Stratum griseum centrale. A central gray layer, recognized as zone 7 of Ramón, appears not to have been determined by Bellonci, probably is included in either his sixth or fifth layer. Its neurons contribute to important efferent pathways. Strata 2 and 3 are Cairney's general afferent layer $(d)$ with the associated cells. 
4. Stratum album centrale. This layer represents the 'zona fibrilar central' of Ramón and the fifth layer of Bellonci. It represents a major component of the most important efferent fiber layer of the tectum and is included in the stratum profundum of mammals. This is the main fiber layer (c) of Cairney.

5. Stratum griseum periventriculare. This layer includes zones 5, 4, and 3 of Ramón and layers 3 and 4 of Bellonci. It is the tectal part of the mesencephalic periventricular gray of mammals.

6. Stratum fibrosum periventriculare. This layer is recognized as zone 2 of Ramón and layer 2 of Bellonci. It represents the tectal part of the mesencephalic periventricular fiber system of mammals. Strata 5 and 6 represent layers $b$ and $a$ of Cairney, respectively.

\section{Description of cellular material}

Each of the basic tectal layers or strata with its various subdivisions will be considered first as seen in characteristic cross sections in toluidin blue material, taken in the midtectal region of the lizard's brain, in which the layers are most evident, and then considered by way of comparison with similarly prepared preparations and selected regions of the brains of turtles, snakes, and alligators.

1. Stratum opticum. This stratum is present in all reptiles studied, although its proportionate size varies in any animal with the plane of section. Within the group this layer coordinates directly with the development of the eye. It is the region of passage of optic tract fibers. In certain reptiles, as in Natrix, for example (see the account of the optic tract on page 91), such fibers may turn from the dorsal surface for a large part of their course, leaving a free zone. On the dorsal surface of the tectum this stratum opticum becomes very thin.

2. Stratum fibrosum et griseum superficiale. This stratum varies greatly in the different orders of reptiles, and even to some extent within the same order. Its relative size in rela- 
tion to the width of the whole tectal area is illustrated in figures 1 to 4, where the tecta of Anolis, Heloderma, Alligator, adult and young Chelhydra, Natrix, and Thamnophis are drawn to scale. Such relations require no further explanation. Attention is now directed to the finer differentiation of this stratum. It appears most highly differentiated in the tecta of certain lizards, such as Chameleon (Ramón, 1896, and Shanklin, '30), and in Anolis (figs. 1 A and B, 3 A), Holbrookia, and Phrynosoma available in this laboratory. In these lizards the stratum album et griseum may be divided relatively readily into three bands of fibers (zones 13, 11, 9 of Ramón) alternating with three rows of cells (zones 12, 10, 8 of Ramón). For the sake of clearness in description, such bands of fibers and rows of cells may be regarded as constituting superficial, intermediate, and deep layers.

a) The stratum fibrosum superficiale superficiale consists of a narrow band, parallel to the surface of the tectum, and containing small neurons which collect toward the outer border into a distinct row of cells.

b) The stratum griseum superficiale superficiale has small but very deeply staining cells arranged in a band two or three cells thick.

c) The stratum fibrosum fibrosum superficiale intermedialis is a layer of fine fibers similar to $a$, and, like it, also parallel to the surface. Both of these fibrous layers are largely regions of synapse.

d) The stratum griseum superficiale intermediale is composed of a single row of somewhat scattered cells comparable to those decribed under $b$.

e) The stratum fibrosum superficiale profundum is a thin fiber band and region of synapse.

f) The stratum griseum superficiale profundum is a row of cells parallel to the surface of the optic tectum and to the gray layers mentioned under $b$ and $d$. It is a very thin layer, but distinct.

The above subdivisions of the stratum fibrosum et griseum superficiale, definable in Anolis, Holbrookia, and Phrynosoma 
(as well as in the Chameleon) undergo certain modifications even in the lizards. Thus in the gila monster (Heloderma suspectum, fig. $3 \mathrm{~B}$ ) the layering within this stratum is less evident than in the forms just described for the stratum fibrosum superficiale superficiale is reduced, the stratum fibrosum intermediale is indistinct, and three of the gray bands are composed only of scattered cells, there being present only a trace of the stratum griseum superficiale profundum. In Varanus griseus the layering, while not as clear as in Anolis or Phrynosoma, is slightly clearer than in Heloderma, for the stratum griseum superficiale superficiale, while not large, in certain regions at least is present as an evident band of cells, several neurons thick, and the fiber bands superficial and deep to it are relatively well defined. In these superficial fibrous bands in this form there are found many intercalated cells, however, without presenting the arrangement characterizing the homologous cells in Anolis, Holbrookia, and Phrynosoma. The stratum fibrosum superficiale profundum and the layer of gray just internal to it are less distinct in Varanus than in the other lizards, the gray layer being represented by little more than a massing of the cells in certain regions and is unrecognizable elsewhere.

The differentiation of the stratum fibrosum et griseum superficiale in the young alligator (Alligator mississippiensis, fig. 3 D) is comparable to that found in the lizards. As with Varanus, the lamination is not quite as distinct as in Anolis. In the alligator all the laminae are present, but are differentiable with ease only in favorable fields. Thus in carefully chosen regions the superficial and intermediate gray subdivisions of the stratum appear as two distinct rows of cells separated by a fibrous band, the stratum fibrosum superficiale intermediale, but even in other portions of the same crosssectional area the two gray bands may fuse. The deeper of these two bands (or the united band as the case may be) is separated by a definite fibrous layer from the scarcely distinguishable stratum superficiale profundum. A point of structural resemblance between the alligator and certain 
lizards is the presence in both of a fairly definite row of cells at the outer border of the stratum fibrosum superficiale superficiale.

In turtles (figs. $2 \mathrm{~A}$ and $4 \mathrm{E}$ and $\mathrm{F}$ ) the stratum fibrosum et griseum superficiale is easily recognizable, but the distinctness with which its subdivisions are seen depends upon the turtle under consideration. Five different turtles were studied carefully with this in mind. The material indicates that the layering becomes progressively less clear in passing from Chrysemys and Emys through musk turtle (Sternotherus) to the adult Chelhydra and is least clear in the 6-day-old Chelhydra in which a condition is found approaching that to be noted for certain snakes. In Chrysemys punctata there is to be observed a superficial, an intermediate, and a deep layer of the stratum fibrosum superficiale, each layer containing intercalated cells. The first two fibrous layers are relatively distinct, but the deep layer is somewhat indefinite, due to the place to place fusing of the deep and intermediate gray layers of the stratum. The superficial gray layer is a thin but relatively evident band of small, lightly staining neurons; the intermediate and deep gray layers, where separable, consist of two thin lines of widely spaced, faintly staining cells. The condition in Emys resembles closely that described for Chrysemys, with no significant variations to note. In Sternotherus the differences are those of degree. The intermediate and deep gray layers (stratum griseum superficiale intermediale and stratum griseum superficiale profundum) are very indistinct and the intervening fibrous bands poorly delimited. In the adult Chelhydra, the stratum griseum superficiale profundum is no longer differentiable as a definite layer, although a few scattered cells at the appropriate level may be considered as its representative. The stratum griseum superficiale intermediale is also poorly developed in the adult Chelhydra and is recognized only in the most favorable fields, finding representation elsewhere in a few lightly staining scattered cells. The stratum fibrosum superficiale profundum, which in many reptiles intervenes between the 
deep and the intermediate gray layers, in these turtles is intermingled in certain places with the deep gray layer. In the tectum of the 6-day-old Chelhydra (fig. 4 F) even less differentiation is observed. For while a stratum opticum and an underlying fibrous layer (which in part also carries optic fibers) with a few intercalated cells are visible, the stratum griseum superficiale superficiale while recognizable cannot be differentiated clearly at all levels from the scattered cells internal to it in the stratum fibrosum superficiale intermediale and the deep and intermediate layers of gray and fibers are represented by scattered cells and fibers. Occasionally the region shows a faintly differentiated band, the stratum griseum superficiale intermediale separating the two adjoining bands, the stratum fibrosum superficiale intermediale and the stratum fibrosum superficiale profundum. No clear stratum griseum superficiale profundum has been demonstrated, though very faint traces of it are seen occasionally in the preparations. Figure $4 \mathrm{~F}$ illustrates the usual picture.

The stratum fibrosum et griseum superficiale of snakes resembles less that of lizards than that of certain turtles. In the three different snakes studied, Thamnophis (figs. $2 \mathrm{~B}$ and $4 \mathrm{H}$ ), Natrix (fig. $4 \mathrm{G}$ ), and Python, internal to the stratum opticum is found the stratum fibrosum superficiale superficiale, which contains relatively numerous intercalated cells, particularly in the garter snake, Thamnophis. The remainder of the stratum fibrosum et griseum superficiale consists of a broad band of cells and fibers, which, however, fails to show clearly the arrangement described for lizard and certain other reptiles. In the garter snake there is not definite layering but rather a subdued striation of the broad cellular band which constitutes the major portion of this area. This striping is due to the presence of more deeply staining cells, and these are more noticeable in the lateral than in the medial part of the field. Since the stratum griseum superficiale intermediale and the stratum griseum superficiale profundum are inseparable, no fiber layer comparable to the stratum fibrosum superficiale profundum of lizards, alligators, and turtles 
can be seen. The stratum fibrosum superficiale intermediale is represented by fiber fascicles intermingled with cells, the latter increasing toward the outer border to form a very indistinct stratum griseum superficiale superficiale. Substantially similar relations are met with in Natrix, where inside of the superficial layer of the stratum fibrosum superficiale the remainder of the stratum is represented by a broad band of gray containing certain more deeply staining cells (possibly representative of the stratum griseum superficiale superficiale) and a band of more scattered inner cells. Any clear delamination of the area into gray and fibrous layers is not demonstrable in the material. In Python, internal to its superficial fibrous layer, the stratum fibrosum et griseum superficiale is occupied by scattered cells which now and again show some faint attempts at band formation, but which present nothing sufficiently definite to admit of satisfactory comparison with the layers of the corresponding stratum of the lizard or alligator.

The foregoing account of the stratum fibrosum et griseum superficiale serves to illustrate certain points with reference to the reptilian tectum. The stratum as a whole is an obvious and important constituent of the optic tectal region of all the reptiles studied, and probably of all reptiles, but the differentiation into obvious layers varies in different forms, showing definite layers in Anolis, less definite layers in Varanus and Alligator, a graded series in turtles (with the layering becoming progressively less distinct through Chrysemys, Sternotherus, and Chelhydra, and finally young Chelhydra) and with the layering quite inevident in the snakes, as, for example, in Thamnophis.

In many of the reptiles studied, the gray of the stratum fibrosum et griseum is discontinuous, any connection with the opposite side being evidenced only by scattered cells. Such fibers as pass from one side to the other (and they are not demonstrable in all preparations) appear to do so by joining the commissural fibers of the next deeper stratum. However, in certain lizards, as, for example, in Anolis, the gray and 
fibrous layers of the stratum can be traced to corresponding regions of the other side. This continuity of the gray is most marked for the stratum griseum superficiale superficiale. There is a tendency for the two deeper gray strata to merge into a single midline group of gray which is sometimes continuous with that of the overlying midline superficial layer. In silver preparations fine fibers mark the continuity of the fibrous layers in properly selected fields.

3. Stratum griseum centrale. This stratum is well represented in all reptiles studied, although relative as well as actual differences in size as well as degrees in differentiation occur in the different forms (figs. 1 to 4). In Anolis (figs. $1 \mathrm{~A}$ and $\mathrm{B}$, and $3 \mathrm{~A}$ ) it consists of a gray band definitely separable into a superficial and deep portion by a fiber layer (fig. 1 A particularly). In the superficial portion the cells are arranged in two more or less distinct lamellae, are closely packed and staining relatively deeply and are bordered peripherally by scattered cells and fascicles of fibers. These fibers which lie at the boundary between the stratum fibrosum griseum superficiale and the stratum griseum centrale might be included with either layer, their inclusion with the stratum griseum centrale follows precedent (seventh zone, Ramón, 1896; and Ramón y Cajal, '11). The deeper portion of the stratum griseum centrale is composed of small, lightly staining cells, intermingled with large, more deeply staining ones. Silver preparations indicate that there is present a fine plexus of fibers among the cells, these fibers passing in considerable number into the underlying stratum album centrale, without forming many definite fasciculi in the stratum griseum centrale. In Holbrookia, a peripheral and a deep cell band can be identified in the stratum griseum centrale in certain parts of the cross-sectional fields of the midtectal region. In other parts of the same field only a single layer is discernible. External to the gray stratum there are found fiber fascicles. No distinct division into two portions is discernible in the available material of Phrynosoma. Here deeply staining cells either are arranged in groups or now and again in 
rows with fiber fascicles between them. At the outer border of the stratum there is a layer of rather well-defined fibers with only a few intercalated cells. In Varanus griseus (fig. $3 \mathrm{C})$ the stratum griseum centrale has the form of a wide band indistinctly separated into a superficial and a deep layer between which, and also in the deeper layer, are many fiber fascicles. In the superficial portion there are to be found clusters of more deeply staining cells and external to these scattered cells and fibers. While there are to be found groups of more deeply staining cells in the gila monster, Heloderma, in this stratum there is no definite arrangement in two layers in the material for study.

In the American alligator (fig. $3 \mathrm{D}$ ) the stratum griseum centrale consists of a superficial and deep layer of gray not separated by a definite fiber layer. Outside of the superficial layer there is found a thin band of fiber fascicles with a few intermingled cells. The neurons of the superficial layer are scattered and show no definite arrangement; those of the deeper layer are arranged parallel to the course of the fiber bundles.

A consideration of the stratum griseum centrale of turtles (figs. $2 \mathrm{~A}$, and $4 \mathrm{E}$ and $\mathrm{F}$ ) indicates that certain characteristics are repeated in each example. Superficial and deep portions of the gray are present. In the specimens of young Chelhydra (fig. $4 \mathrm{~F}$, opposite $\mathrm{F}$ ) it is possible to separate these portions by a thin fiber bundle, but such a fiber bundle was not identified in the other material. External to the superficial band of cells there may be observed a narrow, limiting band of fibers with a few intercalated cells. In cross sections the superficial gray of the stratum consists of cross and obliquely cut fibers intermingled with scattered cells; the deeper part of the stratum is similarly composed of cells and intervening fibers. The latter run for relatively long distances through the field in cross sections and the long neuraxes of the cells are oriented in the same plane.

In snakes (figs. $2 \mathrm{~B}$ and $4 \mathrm{G}$ and $\mathrm{H}$ ) the stratum griseum centrale is relatively wide; although in the forms studied 
there is to be noted a tendency to differentiation this does not progress sufficiently to warrant recognition of a superficial and deep portion of gray, such as has been described for other reptiles. In Thamnophis (figs. $2 \mathrm{~B}$ and $4 \mathrm{H}$ ) the stratum griseum centrale consists of a wide band of small to medium sized neurons with an occasional more deeply stained larger cell, the latter arranged in strands which in the more peripheral region form longitudinally running bands across the cross-sectional field; external to this are fiber fascicles intermingled with numerous cells. The inner portion goes over without clear demarcation into the scattered intercalated cells of the stratum album centrale. Substantially the same conditions are found in Natrix (fig. 4 G), although in the material studied the cell banding is somewhat more definite in the peripheral portion of the field. The inner boundary is relatively cellular, the stratum passing over without evident demarcation into the scattered cells of the stratum album centrale. Comparable conditions are met in the python in which the stratum griseum centrale is large and indefinitely delimited on the inner border and there are indications of a tendency for the field to demarcate into peripheral and deep layers, but such division is not clear. The evident relation is that of bands of cells alternating with fiber bundles.

The gray of the stratum griseum centrale ceases before the midline is reached and only occasional cells in or near the midline suggest its relation to its fellow of the opposite side. However, in certain lizards and snakes (for example, in Anolis and Natrix) there is continuity of the strata of the two sides across the midline at certain levels.

Certain structural differentiations characterize the stratum griseum centrale in all the reptiles studied, although each group presents special peculiarities. There is evident a tendency for the cells to form peripheral and deep layers, clear in lizards and turtles and much less clear in snakes. In all of the reptiles the neurons of the stratum griseum centrale constitute an important nucleus of origin for the fibers of the stratum album centrale. The fascicles which course among 
their cells and almost obscure those in the deeper portion, as is evident in silver preparations of many reptilian brains, constitute part of the efferent system of the tectum. Moreover, those coursing longitudinally or obliquely across the layer in the transverse sections belong to a considerable degree to the more lateral part of the efferent system, that is those supplying paths which course in lateral portion of the brain stem (such as ventral tectobulbar tracts). However, in forms such as Anolis, the long efferent paths course largely in the underlying stratum album centrale.

4. Stratum album centrale. This stratum is present in all of the reptiles studied; although it varies somewhat in size and in the clearness with which it can be delimited from the overlying stratum griseum centrale. In the lizards, such as Anolis (figs. $1 \mathrm{~A}$ and $\mathrm{B}$, and $3 \mathrm{~A}$ ), it is relatively elearly delimited and carries the majority of the efferent fibers of the region (see account of the stratum griseum centrale). Similar conditions exist in Phrynosoma, but in Varanus griseus the more dorsolateral and then lateral portions of the efferent paths course through the lateral part of the stratum griseum centrale, particularly its deep portion, leaving the more medial portion to the stratum album centrale. Conditions comparable to those found in Varanus are found in the alligator. In the turtle, as adult Chelhydra (fig. $4 \mathrm{E}$ ), the stratum album centrale is narrow and carries particularly fibers for the tractus tectobulbaris dorsalis (or medialis) and closely associated paths and also forms the larger part of the superior collicular commissure. The remainder of the large efferent systems course in the tectum chiefly through the stratum gxiseum centrale. In snakes (figs. $2 \mathrm{~B}$, and $4 \mathrm{G}$ and $\mathrm{H}$ ) the boundary between the stratum album centrale and the stratum griseum centrale is not clean cut, scattered cells being found among the fibers of the former area as well as in the deeper portion of the latter area. The fibers entering the efferent tectal paths in these forms course partly through the gray and partly through the white stratum. 
5. Stratum griseum periventriculare. This stratum includes the layers 3 to 5 of Ramón (1896). Its characteristic arrangement is that of rows of deeply staining cells separated by fiber fascicles. Sometimes the deepest cell layer (zone 3 of Ramón) is bounded by a wider fiber band than are the other cell rows, but aside from this the cells and fibers constitute a layer presenting structural uniformity. Although in Anolis (fig. 3 A) such a separated inner cell band of the periventricular gray can be distinguished in favorable fields, it is evident that it constitutes an integral part of the general gray mass. In this form the combined periventricular gray consists of 3 or 4 parallel bands composed of deeply staining, closely packed cells separated by 2 fiber bands. Medially, these cells are displaced by more or less scattered cells, among which or in relation with which are to be found cells of the mesencephalic root of the trigeminal. Certain of these trigeminal mesencephalic cells lie farther lateralward in connection with rows of cells and fibers of the tectal periventricular gray. In Holbrookia the conditions are essentially different to those found in Anolis. The deepest row of ventricular cells is at some distance from its neighbor in certain parts of the field but fuses with it more medially. The strata of the two sides are interconnected in the midline by scattered cells among which (as well as laterally) are cells of the mesencephalic nucleus of the trigeminal. Laterally, the tectal mesencephalic periventricular gray becomes continuous with the remainder of the mesencephalic periventricular gray and caudally it bears the usual relations to the interior colliculus (see p. 59). The sections of the horned toad and the gila monster show that the periventricular gray in these forms bears marked resemblance to that described for the other lizards, except for slight differences in the number of rows of cells. In Varanus griseus (fig. $3 \mathrm{C}$ ) the stratum is poorly developed. The innermost row of the periventricular gray is very narrow and consists of neurons with cells of the mesencephalic nucleus scattered among them and in the midline. The remainder of the periventricular gray is represented in 
most places by 2 or 3 rows of not very closely packed or very deeply staining cells separated by thin fiber fascicles. In parts of the cross-section field such rows of cells almost completely disappear. In the young American Alligator (fig. $3 \mathrm{D}$ ), the stratum griseum periventriculare resembles closely that of the lizard, except that the fiber bundles separating the innermost cell rows from the remainder of the gray are rather wide. As usual, the strata of the two sides become continuous in the midline through cells interspersed with those of the mesencephalic nucleus of the trigeminal which lie here and also in the more lateral part of the area.

In the turtles (figs. $2 \mathrm{~A}$ and $4 \mathrm{E}$ and $\mathrm{F}$ ) the stratum griseum periventriculare shows the same general relations as in the lizards studied, but it consists of more layers and represents a relatively more conspicuous part of the tectal field. It is the outer portion of the periventricular gray (zones 3 to 5 of Ramón) which presents this increase in size when compared with the corresponding area in lizards. It may be from 5 to 6 rows in thickness, with more or less parallel fiber fascicles between the rows.

In the snakes studied, the arrangement of the periventricular gray into rows of cells, characteristic of this area in lizards, alligators, and turtles is very inevident (as in Python) or entirely lacking. In Python the stratum griseum centrale is a wide gray layer, with cells showing some suggestion of arrangement into rows, but not nearly as definitely so as seen in turtles and lizards. The band is continued across the midline by cells intercalated in the course of commissural fibers. Cells of the mesencephalic nucleus of the trigeminal lie in relation with this stratum, more particularly in the caudal part of the area. In Natrix (fig. $4 \mathrm{G}$ ) and in Thamnophis (figs. $2 \mathrm{~B}$ and $4 \mathrm{H}$ ) a layering of the stratum griseum periventriculare is even less evident. In none of the snakes studied could a distinct cell row, comparable to zone 3 of Ramón, be demonstrated. So far as it has representation, it is merely through scattered cells. It is not the purpose of the present paper to enter into an account of the nuclear 
group to which the neurons of the mesencephalic root of the trigeminal may be allotted. Various descriptions of these nuclear groups are to be found in the literature. Reference is here made to the early contribution of Rabl Ruckhard (1894) on snakes, to the observations of van Valkenburg. ('11), and to the more recent and comprehensive account of Weinberg ('28). Recently Shanklin ('30) has studied the grouping and number of the cells of the mesencephalic root of the trigeminal as found in Chameleon.

6. Stratum album periventriculare. This stratum represents the optic tectal portion of the mesencephalic periventricular fiber system, together with a rich dendritic plexus from cells of preceding layer. It is present in all the reptiles studied (figs. 1 to 4 ). There may be observed a difference in the thickness of this stratum in the different forms, but since the fibers are seldom felted and thus form a loose plexus, no special significance can be attached to such variation at present.

Internal to the stratum album periventriculare is to be found the ependymal layer of the ventricle (figs. 1 to 4). For the purpose of the present report it is sufficient to state that this varies in thickness and in the depth of straining in the different reptiles studied and also varies in thickness in different parts of the same reptilian tectum.

Before proceeding to a consideration of the fiber connections of the tectum, certain facts obtainable from a study of Golgi preparations may be summarized here. To a large extent there is an evident agreement between the neuron types found in the present study of Golgi preparations of brains of recently hatched specimens of Pseudoemys elegans and those described by Ramon (1896) for Chameleon and reviewed by Ramón y Cajal ('11). However, it is deemed desirable to note certain differences in results obtained, since certain of these differences appear to have significance. Since the figure presented portrays the form and relative size of the neurons especially considered, the description given may be largely limited to an emphasis of important relations. 
It has been previously pointed out that in various reptiles the optic tract does not extend quite to the surface of the tectum. In this superficial fiber free zone occasional neurons are found. A neuron of this type is illustrated in figure $5 \mathrm{~A}$. It resembles neurons present in the stratum fibrosum et griseum superficiale and probably has migrated from that area. This neuron presents a relatively large cell body with dendrites extending horizontally and parallel to the surface, dividing in rich terminal arborizations which come in relation with the optic tract fibers. The neuraxis appears to enter the stratum fibrosum et griseum superficiale, though its final ending is not determinable in the material. At B, in figure 5, the richly arborizing terminations of the optic tract fibers are illustrated. This arborization occurs in the fibrous layer of the stratum fibrosum et griseum superficiale.

In the stratum fibrosum et griseum there were identified in Chameleon several cell types, certain of which possessed very richly branching dendrites. In none of the turtle material is there to be noted impregnation of such rich dendritic plexuses as those illustrated by Ramón (1896) in cells $\mathrm{H}$ and $\mathrm{H}^{\prime}$ of his figure 12. For purpose of general description, the neurons. found in the stratum fibrosum et griseum may be considered as falling into one of three groups: $a$ ) those neurons possessing neuraxes which distribute chiefly in the stratum fibrosum et griseum superficiale and the outer portion of the stratum griseum centrale; $b$ ) neurons possessing neuraxes which extend to the deeper bundles of the stratum griseum centrale and to the stratum album centrale, and, c) horizontal cells. The first group is illustrated by the neuron $\mathrm{C}$ of figure 5 . Particular attention is directed to the neuraxis of cell $\mathrm{D}$, which gives off collaterals to the stratum fibrosum superficiale profundum in its course to the superficial fiber layer of the stratum griseum centrale. It resembles cell $\mathbf{F}$ of Ramón, as shown in his figure 13, and is comparable to cell $O$ of his figure 12, the cell body of which is situated so near the tectal surface. The second neuron group of the stratum fibrosum et griseum as noted in the turtle is illustrated in 
cells $\mathrm{E}, \mathrm{F}$, and $\mathrm{G}$, of figure 5. The neuraxes of cells $\mathrm{E}$ and $\mathrm{F}$ arise from dendritic branches, that of cell $G$, directly from the cell body. Cell $\mathrm{F}$ is of particular interest by reason of the fact that its peripheral dendrites can be traced among the fibers of the tractus tectothalamicus et thalamotectalis ventrolateralis. The horizontal cells, the third group of neurons found in this stratum, are thus designated by reason of the fact that the main spread of their dendrites is in a plane parallel to the surface of the tectum. They are here illustrated by cell types $\mathrm{H}$ and $\mathrm{I}$, in figure 5. Ramón found them in the chameleon. They are to be found in both the stratum griseum superficiale superficiale and in the stratum griseum superficiale intermediale.

Several neuron types have been recognized in the turtle material in the stratum griseum centrale. For purpose of description they are here classed in two general groups: a) those with neuraxes coursing toward the periphery of the tectum and, $b$ ) those with neuraxes directed centralward. To the first group belong the cells labeled $J$ and $K$, of figure 5 . The neuraxis of the neuron $K$ definitely approaches the optic stratum, but whether or not it joins the stratum as postulated by Ramón in figure 13 (unlabeled cell) the material available leaves uncertain. Attention is directed to the observation that these neuraxes arise from dendrites, usually near a region of branching. Cell $\mathrm{J}$ presents the further interesting relation of a collateral branch arising from the main peripherally extending neuraxis which turns centralward toward the efferent bundles in the deeper part of the stratum griseum centrale and the stratum album centrale. The second group of neurons, those possessing neuraxes which either enter the stratum album centrale or enter the fiber bundle in the deepest part of the stratum harboring their cell bodies, is illustrated from turtle material in cells $\mathrm{L}$ to $\mathrm{S}$, in figure 5 . Cells $\mathrm{L}, \mathrm{M}$, and $\mathrm{N}$ possess relatively large cell bodies and probably are comparable to various larger cells figured by Ramón (1896; cell C, fig. 12 and cell D, fig. 13) for Chameleon. The dendritic spread of these larger cells is noteworthy and pre- 
cludes any strict type of localization of incoming impulses. Cell 0 , figure 5, presents interest in that its neuraxis arises from a peripherally directed dendrite, but curves back toward the deeper layers, probably to enter the stratum album centrale. This neuron is comparable to types figured for Chameleon by Ramón (see cell $R$, fig. 12 of his paper). The remainder of the cells shown for this layer reveal typical, medium-sized neurons possessing dendrites which spread through the stratum fibrosum et griseum superficiale and neuraxes directed toward the stratum album centrale or entering the efferent bundles within the deeper portion of the stratum griseum centrale. Frequently, though not invariably, the neuraxis arises from a dendrite rather than from the cell body. Cells $\mathrm{Q}$ and $\mathrm{S}$, figure 5, are of interest in that their dendrites extend not only toward the superficial gray and fiber stratum, but also pass centralward to come into relation with stratum griseum periventriculare. The neuraxis of neuron $S^{\prime}$ gives off collaterals to the fiber bundles in the stratum griseum centrale and terminates by means of a T-shaped division within the stratum album centrale, the branches passing in opposing directions.

The stratum album centrale contains certain scattered neurons deserving consideration. One of these, which is comparable to certain of the giant ganglion cells illustrated by Ramón for Chameleon (fig. 11, E), lies at the edge of the stratum album of the turtle and is illustrated by the neuron labeled U, in figure 5. Many of the neurons of the stratum griseum periventriculare, observed in the available Golgi preparations of turtle material, present the same general characteristics as do the cells described by Ramón for Chameleon. In general, they possess a medium-sized cell body of ovoid form with short, basilar dendrites ramifying in the fiber fascicles present between the rows of cells or extending down into the stratum fibrosum periventriculare and present further a much longer apical dendrite. While such apical dendrites are relatively long, and branch and rebranch, they extend relatively directly toward the surface and do not present 
noticeable spread in either frontocaudal or mediolateral direction. Brief mention may be made first of those neurons observed which correspond more or less closely with those figured by Ramón (1896, fig. 9). In figure 5, the neuron labeled $\mathrm{V}$ is comparable to neuron D, of Ramón's account, except that neuron $\mathrm{D}$ is situated in a deeper row of periventricular gray. Neurons of this type have a neuraxis given off in the stratum griseum centrale which forms a loop and runs ventricularward to reach the stratum album centrale. Another type of periventricular neuron figured by Ramón (C, fig. 9) has a neuraxis taking origin from an apical dendrite, at or near its bifurcation in the stratum griseum centrale. Such a neuraxis may course peripheralward for a short distance, but returns in course, arborizing to help form a rich plexus in the deeper part of the stratum griseum centrale. The homologous neuron in the turtle ( $W$ of fig. 5) has a neuraxis which, after branching in the stratum griseum centrale, enter the stratum album centrale. The other two types of periventricular neurons figured by Ramón (cells B and $\mathrm{E}$, of fig. 9) are best illustrated in the turtle type in those labeled $\mathrm{X}$ and $\mathrm{X}^{\prime}$ in figure 5. Ramón was able to trace the neuraxis of his neuron $\mathrm{E}$ into the optic tract layer. In the Golgi material of turtle at our disposal it was not possible to trace the neuraxis of this cell type beyond the outer part of the stratum fibrosum et griseum superficiale. In addition to the above types, which bear a more or less close resemblance to the neurons previously described, certain other neurons can be demonstrated in the available turtle material which present relations not hitherto identified. These fall into two general groups: a) neurons with neuraxes which enter the stratum album centrale and, $b$ ) neurons which send neuraxes to the stratum fibrosum periventriculare. Of the first group, two illustrations are given (fig. 5). A study of these figures indicates that the neuraxes are given off either in the periventricular layer or in the stratum album centrale and enter the latter structure without coursing through the stratum griseum centrale. The difference in size of cell body 
and general appearance of neurons $\mathrm{Y}$ and $\mathrm{Y}^{\prime}$, is illustrated sufficiently in the drawings. The second group of periventricular neurons, which show relations other than those figured by earlier workers are illustrated in neuron Z, of figure 5. Such neurons are not as plentiful in the preparations as are the other types described and figured as components of this stratum. In fact, they are very rare, indeed. As concerns these the point of special note relates to the fact that their neuraxes are directed toward the periventricular fiber bundles, though it has not been possible to trace these to their termination. Attention is called to the very rich dendritic plexuses present between the rows of cells and the extension of certain of the dendrites into the stratum fibrosum periventriculare.

A discussion of the mesencephalic neurons, the cell bodies and processes of which are impregnated in certain of the turtle material, will be relegated to a later communication in which the slowly accumulating data with regard to certain relations of these cells can be presented with certain emphasis and detail. It is sufficient to state here that in the turtle many such neurons are of multipolar form, and, so far as the evidence now goes, particularly those found in the caudal part of the median nuclear group. The cell bodies of the mesencephalic root of the trigeminal may send processes into the stratum album centrale, which enter the mesencephalic root either directly, or in certain cases following a T-shaped division. Other processes are directed toward the ventricle. Certain medially situated cells of the nucleus send dendrites toward the tectal commissures. According to Weinberg ('28), some may decussate here. Others extend out through the stratum griseum centrale; they may possibly reach even more peripherally situated tectal areas.

Golgi preparations of the turtle material indicate the presence of ependymal cells similar in all essentials to those figured by Ramón (1896) and Ramón y Cajal ('11). Such elements have cell bodies situated along the ventricle and processes radiating out toward the periphery. They are not figured. 


\section{Fiber connections of the optic tectum}

In the following description, with minor exceptions, of necessity consideration is limited to the tectal components of the respective paths. Many of the apparent exceptions to this statement are in reality only nominal, since they are descriptions of connections with centers which are important regions of synapse in the course of afferent or efferent tectal paths. It has not been the purpose of this account to give in detail all possible tectal paths, but rather to confine consideration to tectal paths which possess certain recognized functional significance and illustrate certain functional patterns to emphasize what is given here. The consideration of certain pathways, the discussion of which is here omitted, awaits detailed presentations of certain diencephalic centers.

Optic tract. The optic tract of reptiles has been studied and more or less completely described for these forms by various observers. Among the earlier students of this fiber system may be mentioned Stieda (1875), Bellonei (1888), C. L. Herrick (1891 and 1893), Ramón (1896), Edinger (1899 and '08), Gross ('03), Gisi ('07), and Ramón y Cajal ('11). Then followed the accounts of de Lange ('13), Ariëns Kappers ('20-'21), Huber and Crosby ('26), Cairney ('26), Shanklin ('30), and others. Certain of the results thus obtained will be summarized briefly.

Bellonei (1888), working with such forms as snakes, turtles, and lizards, recognized a superficial optic tract, the lateral or marginal tract of many observers. In addition, he described two more deeply situated tracts. Of these latter the outer is partly, perhaps wholly, comparable to the axillary optic tract of later terminology. The inner tract belongs to the dorsal supraoptic system, more particularly to its lateral portion, sometimes termed the tractus tecto-thalamicus et thalamo-tectalis cruciatus. In his study of the chameleon brain, Ramón (1896) found, in addition to a marginal optic tract, a 'fasćiculo óptico-comisural' which he believed to be partly commissural and partly optic. This is represented in part, as was the deepest path of Bellonci, in the crossed 
tecto-thalamic and thalamo-tectal portion of the supraoptic decussation, but it is believed to include also the axillary optic tract. de Lange ('13) figured the main or marginal optic tract and the basal optic root 'radix nervi optici basalis.' These same tracts had been described earlier by Edinger (1899). Beccari ('23) recognized a marginal and an axillary optic tract and a basal optic fasciculus. His axillary tract is shown to join fibers of the supraoptic decussation (Beceari, 23, fig. 17, p. 587). The combined bundles would be the homologue of the fasciculus optico-commissuralis of Ramón. Huber and Crosby ('26) identified and traced the marginal and axillary optic tracts and the basal optic root in the alligator. The fibers joining the marginal optic tract were regarded as being commissural rather than optic and were described with the supraoptic decussation under the of the tractus tecto-thalamicus (et thalamo-tectalis) cruciatus. In Sphenodon Cairney ('26) described relations in essential agreement with those given for the alligator. Shanklin's figures ('30) show a marginal optic tract (tractus opticus medialis and tractus opticus lateralis) and a basal optic root, in the chameleon. In connection with this system is a brachium tecti medialis which will be described later (p. 87).

The optic nerve and tract have similar relations in all of the reptiles studied. As the optic nerve fibers reach the chiasm, they break up into relatively large fascicles and, alternating with similar bundles from the contralateral nerve, decussate completely. The relatively large size of these fascicles and the pattern they form has been emphasized by Gross ('03) in his study of the optic nerve of reptiles. After decussation, the fibers, which now constitute the optic tract, take up their position on the superficial surface of the brain and pass dorsocaudalward to their termination. Two portions of the tract may be recognized: 1) a marginal portion and, 2) a smaller axillary portion. In the following accounts the tectal relations and connections of the two portions of the optic tract are emphasized. 
The description of the optic tract of lizards is based primarily on preparations of the brain of Anolis carolinensis. The material of the other lizard brains available has been studied, and is so much the same that separate descriptions are unnecessary. Excellent material of the brain of horned toad shows practically identical relations.

Tractus opticus pars marginalis in Anolis (figs. 6 and $7 \mathrm{~A}$ ) passes lateralward and slightly dorsalward, immediately after the decussation and then courses directly dorsalward. For some distance at the lower border of the tectum the marginal optic tract is joined by fibers of the axillary optic tract, both distributing to the tectum. The axillary part reaches largely, probably exclusively, the cephalic and medial part of the optic tectum. From this lower border of the tectum the fibers continue dorsalward (and slightly frontalward) and cover over the anterior surface of the tectal area, forming a pars cephalica. Then the tract bifurcates and a medial and a lateral portion encapsulates the ventral, medial, and dorsomedial, and the lateral and dorsal surfaces, respectively. Followed caudally in cross section material, the pars medialis becomes separated soon after its origin from the main band of optic tract fibers. After its separation, it is joined by a few bundles of the tractus opticus axillaris (fig. $6 \mathrm{~A}$ ). The pars medialis of the marginal optic tract and the associated pars tectalis of the axillary optic tract extend caudalward along the medial tectal wall distributing throughout their course to the underlying stratum fibrosum et griseum superficiale. The tractus opticus marginalis pars medialis (with associated axillary fibers) due to its mode of distribution grows progressively smaller as it is followed caudalward, but throughout its extent is detectible from the lateral part of the optic tract at most planes. At the caudal end of the tectum the bundle extends on to the dorsal surface, where it comes into relations with the posterior part of the marginal tract. The medial part is very small in planes through the oculomotor nucleus and soon thereafter disappears. 
The lateral part of the marginal optic tract (Anolis, figs. 6, $7 \mathrm{~A}$, and 10) is slightly smaller than the medial part just described at the place of separation of the two portions. This pars lateralis is added to throughout much of its extent from the main marginal bundle. It extends over the dorsal portion of the tectum. At first the dorsal band is relatively wide, but its narrows in course so that there is an area in the caudal part of the middle third of the tectum where most of the fibers have turned in and very few optic fibers reach the dorsolateral surface area. As the caudal end of the tectum is reached, the main bundle of the optic tract which has contributed to the pars lateralis throughout its extent sends fibers not only along the lateral wall, but swings over the caudal tectal area in what may be termed a pars caudalis. This caudal portion (which is really continuous with the pars lateralis) has ventromedial fascicles which swing medialward over the ventral caudal surface to the medial tectal wall and dorsal bundles which swing over the caudal surface and on to the dorsomedial wall along which they run forward to supply the tectal area up to levels through the oculomotor nuclei. In crosssectional planes just caudal to the separation of the medial from the lateral part of the tractus opticus marginalis is situated the nucleus lentiformis mesencephali (fig. 6 B). Across this nucleus between the medial and lateral optic bundles extend fine fibers which correspond to the tract in Chameleon described by Shanklin ('30) as homologous to the brachium tecti medialis of fishes. The evidence at hand at present, while not conclusive, suggests that these fine fibers are optic fibers which synapse in part at least in the nucleus lentiformis mesencephali on their way to the tectum. It may be hypothecated that this nucleus is the homologue of the mammalian nucleus designated nucleus opticus lateralis. This brachinm tecti medialis is particularly clear in the Varanus material available for study.

The bundles forming the axillary optic tract (figs. 6 and $7 \mathrm{~A}$, also Huber and Crosby, '26, figs. 19 and 20) after decussation in the chiasmal region form the most internal part of 
the optic tract for a short distance, then separate from it. Many of the fascicles enter the ventral and medial portion of the main lateral geniculate nucleus (nucleus geniculatus lateralis pars ventralis of Cairney, '26) where they give off collaterals and probably stem fibers. It is difficult to determine definitely in normal preparations to what extent they end in this nucleus. Some of the bundles of the axillary optic tract region reach the marginal optic tract without synapse in the diencephalic centers and so constitute a tractus opticus marginalis pars tectalis. The more eephalic of such bundles rejoin the marginal tract and distribute with the pars cephalica and pars medialis. The more caudal bundles come into relation with the medial part of the marginal optic tract after its separation from the lateral part and distribute with it (fig. $6 \mathrm{~A}$ ). In its course to the tectum the fibers of the axillary optic tract lie in intimate relation with fibers of the tractus tecto-thalamicus et thalamo-tectalis ventrolateralis and the more lateral components of the dorsal supraoptic system (the tractus tecto-thalamicus et thalamo-tectalis cruciatus of the alligator).

Within the tectal area the fibers of both marginal and axillary tracts turn in from the surface and break up in terminal plexuses in the superficial, intermediate, and deep fibrous layers of the stratum fibrosum et griseum superficiale (fig. $5 \mathrm{~B})$. Their connections within the area will be discussed later. By means of these various bundles the optic tectum is covered by optic tract fibers except for much of its region of attachment where it lies in relation with various subtectal gray masses.

In addition to the tectal connections of the optic tract there are, as is well understood, numerous diencephalie, subtectal, and tegmental connections. For the present purpose these need not be described; various more or less complete accounts of them are to be found in the literature (contributions of Ramón, 1896; Edinger, 1899; de Lange, '13; Beccari, '23; Huber and Crosby, '26; Cairney, '26, and others). Brief reference is made here to the distribution in these areas 
merely because many of the areas in turn have tectal connections. Optic tract fibers other than those to the tectum, have the following general distributions: $a$ ) to the main lateral geniculate nucleus, homologue of the nucleus geniculatus lateralis pars ventralis of mammals and associated gray of the region; $b$ ) to a differentiated nuclear region receiving optic tract fibers, the probable homologue of which in Sphenodon Cairney ('26) and Durward ('30) suggested might be the forerunner of the mammalian nucleus geniculatus lateralis pars dorsalis; $c$ ) to certain subtectal and pretectal areas, for example, such as the nucleus lentiformis mesencephali; $d$ ) to the nucleus posterodorsalis; $e$ ) to the nucleus of the basal optic root. The connections with the nucleus posterodorsalis may be amplified somewhat. A small bundle of optic fibers continues caudalward without entering the tectum (fig. $6 \mathrm{~s}$ ). It occupies a medial position in the subtectal field lateral to the habenular and dorsal to the cephalic part of the posterior commissure.

The tract terminates in relation to a small nuclear mass, beginning lateral to the habenula and extending behind the latter nuclear complex into a position near the midline where it is evidenced in many reptiles by a slight elevation of the dorsomedial surface, dorsal to the posterior commissure This nucleus also receives fibers of the ventrolateral tecto-thalamic tract.

The nuclear mass here indicated while present in many reptiles, perhaps in all, has not been recognized by many students of reptilian material and where recognized has been given a variety of names. It represents the nucleus posterodorsalis of Huber and Crosby ('26), is included in the nucleus geniculatus lateralis pars superior of Shanklin ('30), although less probably the nucleus so designated by Ramón (1896), and certainly not the nucleus geniculatus lateralis pars dorsalis of Cairney ('26) which lies ventral and cephalic to it. Possibly it is a part of the region designated the geniculate nucleus by Warner ('31, p. 1160, fig. 13). For the present the name of the nucleus posterodorsalis is retained, since the 
cell mass is believed not to be homologous with the lateral geniculate nucleus of mammals. It is possible that the optic tract fibers terminating in this nucleus may be comparable to the fasciculus dorsalis of the tractus opticus medialis described by Jansen ('29) for teleosts and carried by him to the nucleus of the posterior commissure, but such an homology needs further verification. The nucleus may be subdivided later.

Passing, now, from a discussion of the optic tract of lizards to a consideration of this system in other reptiles, it soon becomes evident that the pattern described in the preceding pages is common to all forms studied, including alligator, various snakes and turtles (figs. $7 \mathrm{~B}, 8$ to 10). There are minor differences to be seen, such as differences in degree of medullation of fibers in the younger and older material, differences in the actual or relative size of the various components depending either upon the size of the brain, the actual or relative size of the eyes, or both, or differences in the course of the components depending upon the lateral extent of the tectum. Such variations have been noted and might be detailed here at length, but such discussion would add very little to the understanding of the fundamental pattern of the distribution of the optic tract. One peculiarity seems at present worthy of emphasis and that may be stated briefly, as follows. In certain of the turtles (as, for example, in Chrysemys, adult, and particularly in the young Chelhydra) fairly large fascicles of the optic tract turn into the outer part of the stratum fibrosum et griseum superficiale before the dorsal surface is reached and thus the optic tract fibers form an exceedingly thin stratum opticum on portions of the dorsal surface. Now and then they are found nearly or entirely away from the periphery, leaving a very narrow fiber free zone in which are found occasional cells. Such fiber free areas are relatively very small in the adult forms of the turtles mentioned above, but in the young Chelhydra such a fiber free area, although very narrow, extends over much of the tectal surface. The scattered cells found in this area 
in turtles are illustrated in figure 5 A. They resemble certain horizontal cells of the stratum fibrosum et griseum superficiale. They probably represent cells of that type which have migrated a trifle peripheralward. In snakes, such as Natrix, a fiber free zone, narrow but distinct, intervenes between the surfaces of the optic tectum and the stratum opticum throughout much of the tectal course of the optic tract (fig. $10 \mathrm{~B}$ ). The conditions in these snakes resemble those found in young Chelhydra, but are more distinct. Scattered through this fiber free zone in Natrix are found occasional neurons. These fiber free zones have been included with the optic tract fibers in the stratum opticum of snakes to bring its layers in conformity with other reptiles; however, such a zone is probably the beginning of a primitive stratum zonale and stratum cinereum which become more highly developed in mammals.

The supraoptic or postoptic decussations. The supraoptic or postoptic decussations occur in the chiasmal ridge partly dorsal to and partly caudal to the optic fibers, their position varying slightly in different animals. In certain reptilian forms the term 'supraoptic' is the more appropriate, in others the term 'postoptic.' For the sake of uniformity, and following the usage of a number of observers the name supraoptic is applied here to the system no matter whether it crosses dorsal to or immediately caudal to the optic decussation. Various components of the supraoptic decussation have been known for a long time, although variously designated. However, there are as yet many unsolved problems with reference to the relations, connections and functional significance of these systems. Among those who have studied these decussations in reptiles are to be mentioned Bellonci (1888), Edinger (1899), de Lange ('13), Ariëns Kappers ('20-'21), Beccari ('23), Huber and Crosby ('26), and Cairney ('26). Bellonei (1888) described a 'commissura inferior' which he was able to trace to the corpus posterius, but which distributed chiefly to the torus semicircularis (by which he apparently means the superior colliculus, in contradistinction to Edinger's usage; see Bellonci, 1888, p. 15). This observer described 
also fibrae ansulatae and so-called peduncular fibers which he regarded as belongng to this system of decussating fibers, but which in reality represent the basal optic root of later workers. Ramón (1896) identified a commissura inferior comparable to that described by Bellonci and a fasciculus optico-commissuralis, which, as was stated earlier, probably includes both the tractus opticus axillaris and the tecto-thalamic (et thalamo-tectal) component of the supraoptic system. Edinger (1899) and de Lange ('13) recognized a decussatiotransversa; this is comparable to a major part of the dorsal supraoptic or postoptic decussation. The position of the decussatio supraoptica ventralis in and near the chiasmal region is indicated in Edinger's and, to a less extent, in de Lange's figures, but is unlabeled. Ariëns Kappers ('20-'21) figured both dorsal and ventral supraoptic commissures as arising first in reptiles and as concerned with interrelating the neostriatal areas. The ventral commissure was traced to the inferior collicular region, and there is a suggestion of its possible connection with the nucleus isthmi, although the latter connection was not particularly clear in his preparations. Beccari ('23, fig. 7) showed the position of the dorsal and ventral supraoptic decussations in the chiasmal region in an embryo of Lacerta. Figure 6 of the same paper illustrates beautifully the relations of the fibrae ansulatae to the nucleus of the median longitudinal fasciculus. Huber and Crosby ('26) described the supraoptic system in the American alligator. They recognized a dorsal supraoptic system, a tractus tecto-thalamicus (et thalamo-tectalis) cruciatus, a ventral supraoptic decussation, divisible into dorsal and ventral parts and fibrae ansulatae. The ventral supraoptic decussation through its pars dorsalis was found to connect the optic tecta or superior colliculi of the two sides; fascicles of the pars ventralis of this decussation were carried to both superior and inferior colliculi, and a few bundles to the nucleus isthmi. The tractus tecto-thalamicus cruciatus was traced through the chiasmal ridge and dorsalward to its nucleus (nucleus tractus tecto-thalamici cruciati) comparable 
to nucleus geniculatus inferior of Ramón (1896) and Shanklin ('30), where part of the fibers terminate (or begin), while others swing dorsalward to the tectum. This tract was believed to have some relation to preoptic and possibly hypothalamic gray. The decussatio supraoptica dorsalis was carried partly to its nucleus (a differentiation of the entopeduncular group) and partly caudalward; some of the fibers were found to enter the tectum, others passed to unknown terminations through the tegmental areas. In Sphenodon, Cairney ('26) recognized rostral and caudal portions of the dorsal supraoptic decussation and suggested, but could not verify from his material, a connection by means of the rostral part with the neostriatum. The caudal portion of this decussation he carried in part to cell groups comparable to the nucleus decussationis supraoptica dorsalis of Huber and Crosby and in part traced it back into the peduncle. In the decussationis supraoptica ventralis Cairney described, 1) a pars dorsalis distributing in part to the ventral part of the lateral geniculate nucleus and in part coursing to the tectum in company with the ventral tecto-thalamic path of that observer and, 2) a pars ventralis which enters in part at least a nucleus corresponding to the corpus geniculatum internum of Bellonci (1888). Whether or not this tract continues through the tectal region with fibers from the nucleus just mentioned Cairney was uncertain. He found no connections of the pars ventralis with the corpus quadrigeminum posterius. Decussations of the dorsal and ventral supraoptic systems are illustrated in the recent atlas of the brain of Lacerta vivipara by Frederikse ('31).

Turning, now, to a consideration of the supraoptic systems as they are revealed in the material available for study, they are found to be developed to a relatively high degree in the lizard. The conditions described here for Anolis carolinensis may be regarded as fairly typical for the group. The account to be given agrees relatively closely with that given for the supraoptic system in the alligator (Huber and Crosby, '26), but the material permits the addition of certain details and 
the confirmation of certain doubtful points. The discussion will begin with a description of the ventral supraoptic decussation.

The differential staining which permits separation into evident dorsal and ventral parts of the ventral supraoptic decussation in the alligator is not obvious in Anolis. The use of the terms decussatio supraoptica ventralis pars ventralis and decussatio supraoptica ventralis pars dorsalis, therefore, is somwhat arbitrary for the lizard, for while in certain fields the two divisions can be recognized with ease, there is a considerable interchange of fibers from the pars ventralis to the pars dorsalis during their course toward the tectal centers. The dorsal part crosses well forward in the chiasmal ridge, at about the same level as do the more cephalic fibers of the tractus tecto-thalamicus (et thalamo-tectalis) cruciatus (fig. $6 \mathrm{~A}$ ), and is ventral and slightly caudal to this decussation and dorsal to the crossing of the optic tract fibers and is distinguishable through a slight difference in staining. This dorsal part forms a relatively narrow band which swings lateralward and caudalward to a position immediately internal to the optic tract fibers (fig. $6 \mathrm{~B}$ ) and accompanies these toward tectal centers. However, in planes through the most cephalic end of the posterior commissure the more dorsal fibers of the dorsal part of the ventral supraoptic decussation begin to swing somewhat more medialward near to the upper border of the lateral forebrain bundle and to sweep almost directly dorsalward to the tectum (fig. $7 \mathrm{~A}$ ). Many smaller fascicles swing almost straight across the field to enter the layers of the stratum fibrosum et griseum superficiale and the outer part of the stratum griseum. This oceurs throughout the remainder of the course of the bundle (and the rest of the tectum). The fibers can be traced well up on to the dorsal surface and it appears probable that they may extend even farther; certainly, much of the superficial layer is reached by them. The remainder of this slowly diminishing bundle passes at almost right angles to the gradually accumulating tractus tecto-thalamicus dorsomedialis anterior (fig. $7 \mathrm{~A}$ ). 
Ultimately it is joined by certain bundles of this system, the two approaching the tectal region together. Other fiber tracts come into relation with it as it approaches its destination. Finally, the majority of the bundle that remains (together with part of the anterior dorsomedial tecto-thalamic tract) terminates in continuity with the stratum album centrale. The relations of the decussatio supraoptica dorsalis pars dorsalis with both the stratum fibrosum et griseum superficiale and the stratum album centrale suggests that it carries both afferent and efferent fibers with respect to the optic tectum. Near the caudal end of the optic tectal region fibers of the pars ventralis come into intimate relation with fibers of the pars dorsalis of the ventral supraoptic decussation.

The ventral part of the ventral supraoptic system (fig. 6 B) crosses ventral to the dorsal portion, runs lateralward and then dorsolateralward in close relation to the optic tract and not very clearly separated from the dorsal part of the system, although quite well differentiable from it by its difference in coloring. At the level in which the dorsal part swings somewhat medialward the ventral part continues along the inner border of the optic tract (fig. $7 \mathrm{~A}$ ). With the thinning down of these latter fibers as they distribute more and more to the tectum, the main bundle of the ventral part of the ventral supraoptic system reaches a position at the surface of the brain between the optic tract dorsally and the basal optic root ventrally. Here it is intermingled with cells of a nucleus which has been variously named. It has been designated the geniculatum internum by Bellonci (1888), the geniculatum posticum by Edinger (1899), and the 'nucleo s genicolato med. (?)' by Beccari ('23). It is the nucleus which, for lack of a recognized homology, was labeled nucleus $Z$ by Huber and Crosby ('26); reference to this nucleus was made by Cairney ('26) without doing more than homologizing it with various names in the literature. Whatever name is used, it is obvious that this nucleus is in synaptic relation with the pars ventralis of the decussatio supraoptica ventralis of the ventral supraoptic decussation. In the material of Anolis, the indications 
are that a considerable bundle of fibers passes at the lateral side of the nucleus and possibly through it without synapse. A final determination of the amount of synapse which takes place here must be left to experimental work. Joined by fibers associated with this nucleus (possibly afferent to it), the pars ventralis of the ventral supraoptic decussation swings into close relation with the pars dorsalis and passes in part in the optic tectum where it appears to terminate in part in the stratum fibrosum et griseum superficiale and adjacent portions of the stratum griseum centrale and to be continuous in part with the stratum album centrale. A small bundle of the pars ventralis (and the associated fibers from the above mentioned nucleus) can be traced caudalward near the surface of the brain to the inferior colliculus. A few fascicles appear to reach the nucleus isthmi, although the demonstration of this latter connection is not entirely satisfactory. No synaptic relations with the nucleus and no demonstration of the addition of neuraxes to the bundle has been assured by definite observations. Moreover, it cannot be stated definitely that these fibers actually took part in the supraoptic decussation; they were traced only from the geniculatum internum of Bellonci (1888).

It is of interest to note that the tractus tecto-thalamicus et hypothalamicus cruciatus pars posterior, which was described by Herrick ('17) for Necturus and which is suggestive of at least part of the reptilian supraoptic decussation shows certain comparable relations. Thus Herrick found that the bundle was both afferent and efferent with respect to the optic tectum, and that it carried fibers to the nucleus posterior tecti.

The tractus tecto-thalamicus (et thalamo-tectalis) cruciatus (fig. $6 \mathrm{~A}$ and $\mathrm{B}$ ) of Anolis constitutes the most cephalic component of the supraoptic system in the chiasmal ridge. This bundle crosses immediately dorsal to the optic tract fibers and then to the pars dorsalis of the ventral supraoptic decussation. A few fibers of unknown origin appear to join it from the preoptic and anterior hypothalamic region medial to the forebrain bundle. It really constitutes the frontalmost fibers 
of the dorsal supraoptic decussation within the chiasmal ridge. After its crossing the tract runs directly dorsalward and caudalward between the lateral forebrain bundle and the optic tract and enters a small nuclear group associated with the pars ventralis of the lateral geniculate nucleus. This nucleus, the nucleus tractus tecto-thalamici cruciati of Huber and Crosby ('26), is apparently the corpus geniculatum laterale pars inferior of Shanklin ('30; fig. 5, p. 431, and fig. 6, p. 433). Here the bundles break up to some extent among the cells probably in part arising and in part terminating as stem fibers or collaterals. Without synapse in this region certain bundles pass directly dorsalward toward the tectum with the anterior part of the ventrolateral tecto-thalamic tract with which fiber system the tractus tecto-thalamicus is somewhat intermingled. The tecto-thalamic and the thalamo-tectal tract in part enters the tectal layers, particularly the stratum griseum superficiale profundum and the stratum griseum centrale. Certain bundles are contributed to the pretectal nucleus during their tectalward course; other bundles become continuous with the stratum album centrale. These connections strongly suggest the presence, as in other components of the supraoptic system, of both afferent and efferent tracts, with respect to the tectum, in this fiber system. However, the bundles are so intermingled with those of other systems, that as yet an entirely satisfactory analysis of this tract has not been made.

The tractus tecto-thalamicus cruciatus of the alligator (Huber and Crosby, '26) apparently is included in the dorsal part of the ventral supraoptic decussation as described by Cairney ('26). For the first part of its course it is a fact that the tract parallels this decussation, but its staining reaction, its decussation, its general connections, and its relations in the caudal part of its course relate it much more intimately with the dorsal supraoptic system. In fact, the material suggests that the crossed tecto-thalamic path in reptiles is merely the more ventral and lateral portion of a great fan of decussating dorsal supraoptic fibers, the main mass of which 
crosses through the forebrain bundle. In avian forms, where the supraoptic system is developed to a marked degree, this fan of fibers extends in fairly even distribution from the tractus tecto-thalamicus eruciatus to near the ventricular wall, including crossed fibers of the periventricular system together with the fibrae ansulatae. The tractus tecto-thalamicus (et thalamo-tectalis) has relations suggestive of those described by Herrick ('17) for Necturus under the name of the tractus tecto-thalamicus et hypothalamicus cruciatus pars anterior.

The main mass of the dorsal supraoptic fibers (the decussatio supraoptica dorsalis of figures 6 and 7 A) crosses in the chiasmal ridge dorsal to the decussation of the ventral supraoptic system, and interdigitates with the fibers of the lateral forebrain bundle, synapses in part with the special nucleus of the entopeduncular group, contributed to by fibers associated with this nucleus, and then sweeps dorsalward and caudalward to the tectum (fig. $7 \mathrm{~A}$ ). The fibers enter the tectum, distributing in part to the stratum album et griseum superficiale and the stratum griseum centrale, on both the mesial and lateral sides of the tectal area, and extend in these layers toward the dorsal wall. Other fibers join the dorsal supraoptic system from the stratum album centrale. In its tectalward course the dorsal supraoptic decussation crosses the nucleus lentiformis mesencephali and farther caudalward is in relation with the pretectal nucleus and here collaterals are given off and possibly stem fibers arise and end. Certain of the fibers of the dorsal supraoptic decussation pass internal to the stratum album centrale and reach the periventricular gray and white strata. In the gray layers they contribute to the fascicle of fibers between the rows of cells, and in the still deeper stratum fibrosum periventriculare they enter the plexus of periventricular fibers. Other connections of the dorsal supraoptic system, not concerned with the optic tectum, are said to be interstriatal connections (Ariëns Kappers, '20'21) and possibly bundles to the diencephalic and tegmental regions. With regard to the latter type, it is evident that not all the dorsocaudally running bundles reach the optic 
tectum or the gray immediately ventral to it. The termination (or the origin) of these tegmental fascicles is as yet unknown. It has not been possible to identify the interstriatal component in reptiles, although its excellent development in birds and in certain mammals certainly suggests the presence of such fibers. The interstriatal portion becomes incorporated with lateral forebrain fibers in birds, and a similar but more more complete incorporation may hinder its recognition in reptiles. In mammals it provides a decussating portion of the ansa lenticularis.

For those fibers crossing in the dorsal, caudal portion of the supraoptic decussation, the fibrae ansulatae, and associated fibers of the periventricular system, no tectal connections have been identified, consequently they need no further discussion here. There is the possibility that they may carry crossed fibers to the periventricular layer of the tectum, but such have not been demonstrated in the material. They are concerned mainly with subthalamic interrelationships (see Beccari, '23, and Huber and Crosby, '26).

The series of other lizard brains verify more or less completely the results reported here, but add nothing of significance to the present account. Particularly clear evidence of the relations of the dorsal and ventral supraoptic systems to the tectal strata is furnished by the preparations of the brain of the horned toad. A connection with the nucleus isthmi was not established.

A restudy of the alligator material available in the light of knowledge of the connections of the supraoptic systems in lizards, while largely confirmatory, permits the addition of certain details to former accounts, which may be summarized here briefly as follows: The ventral part of the ventral supraoptic decussation besides its previously described connections with the optic tectum and the inferior colliculus, has the usual relations with the geniculatum internum of Bellonci (1888), nucleus $\delta$ of Beccari ('23), $Z$ of Huber and Crosby ('26), etc., referred to in the account of Anolis. To what extent synapse of these fibers occurs in the nucleus is uncertain, the 
relations are less clear in the alligator material than in that of Anolis, but some synapses occur and the tract is joined by fibers as it passes at the side and through the nucleus. In the alligator the inferior colliculus is rolled into the ventricle and the fascicle of the ventral supraoptic system which supplies this gray mass of necessity cuts across the deeper portion of the midbrain in order to reach it. The fibers passing to the tectum, however, swing dorsalward to the optic tectum coming into the usual relations with the dorsal part of the supraoptic decussation and in the material studied the two become practically inseparable. A very small bundle of the ventral supraoptic decussation can be traced to the levels caudal to the tectum and is believed to reach the nucleus isthmi, although actual synaptic connections or entrance of neuraxes from the cells of the nucleus into the bundle could not be established. In the alligator material this small fascicle to the nucleus isthmi appears to form the dorsal part of the decussation, but a comparison with conditions in lizards suggests it may be formed of fibers secondarily incorporated with this portion from the ventral part of the decussation. Such fibers may have crossed in the decussatio supraoptica ventralis pars ventralis or may have joined the bundle in the region of the geniculatum internum (Bellonci, 1888). The dorsal part of the ventral supraoptic decussation and the tractus tecto-thalamicus cruciatus of the alligator not only enter the stratum fibrosum et griseum superficiale, but also receive fibers from the stratum griseum centrale (through the deeper parts of which efferent fibers run in these forms) and in small part at least from the stratum album centrale. Therefore, they appear to carry both afferent and efferent fibers with respect to the tectum. Further consideration of the alligator material has permitted practically no additions to the earlier account of the dorsal supraoptic system. No fibers to the neostriatum can be traced in the material available, although their presence in birds suggests their probable probable presence in reptiles. Also the tectal connections of the tract are not demonstrable in a satisfactory manner, 
although there is every reason to believe that they are entirely comparable to those of lizards. Certain of these relations are indicated in figure $7 \mathrm{~B}$, but for details figures in the 1926 paper (Huber and Crosby) should be consulted.

The turtle material studied adds nothing further to the knowledge of the supraoptic system. For the consideration of this system, preparations of brains of 3-day-old and 6-dayold Chelhydra serpentina proved to be the most useful, since the decrease in the number of impregnated tracts rendered it easier to trace those in question. Dorsal and ventral supraoptic decussations, a tractus tecto-thalamicus (et thalamotectalis) cruciatus and fibrae ansulatae were identified and their more important relations, in conformity with that of other reptiles studied, were established. Many such relations are evident in figures $8,9 \mathrm{~A}$, and $11 \mathrm{C}$.

The supraoptic systems on the whole are not as well impregnated in the snake material available for study. Ventral and dorsal supraoptic systems of course are recognizable. The ventral appears as a continuous decussating band in the chiasmal ridge, then follows the usual course dorsocaudalward. Slight differences in staining sometimes aid in the separation into a dorsal and ventral part. Its more dorsal fibers clearly enter into the usual relations within the optic tectum, distributing in part to the superficial gray layers and leaving in part from the stratum album centrale. The relations of the ventral part of the ventral supraoptic decussation in snakes are illustrated particularly well in Weigert preparations of Natrix where the connections are typical, being very similar to those described for lizards. The nucleus geniculatus posterior of Bellonei (1888) is well developed and a very considerable interruption of the system with the addition of new fibers from the region occurs (fig. $10 \mathrm{~B}$ ). The dorsal supraoptic decussation in snakes presents particular difficulties. Although silver material of the young boa constrictor, of Natrix, of Python molurus and of the copperhead, Agkistrodon mokasen, and Weigert sections of Natrix were available for study, only in the copperhead could the main portions of 
this system be followed satisfactorily to the tectum. In all the snakes studied the dorsal supraoptic system crosses the chiasmal ridge and spreads out dorsolateralward as rather sharply stained but scattered fibers. The crossed tectothalamic (and thalamo-tectal) tract has its usual relations and comnection; the fibrae ansulatae run periventricularly and the scattered supraoptic fibers between fan out through the fascicles of the lateral forebrain bundle. This portion appears to consist of fewer fascicles than the homologues in the other reptiles studied. Beyond this position with relation to the forebrain bundle and certain relations with the specialized entopeduncular group, characterized as the nucleus decussationis supraopticae dorsalis, it has not been possible to trace with certainty the dorsal supraoptic system in most of the snakes studied. However, in the copperhead, bundles of this system joined by fibers from the last mentioned nuclear group can be followed dorsocaudalward and to the tectum where these fibers terminate in part in the stratum griseum et album superficiale. Other fibers, probably efferent with respect to the tectum, pass out of the stratum griseum centrale and the stratum album centrale into the dorsal supraoptic system. Still other fascicles of this system appear to enter the periventricular strata, but this latter relation cannot be established beyond doubt. The fibers of the dorsal supraoptic system which swing caudalward through the tegmental areas were not traced to their destination.

The above account suggests very strongly that the fundamental pattern of the supraoptic decussation is the same in all reptiles. Failure to recognize a certain component or connection in any reptile is more apt to be due to incomplete (or perhaps even too rich) impregnation or staining of the material or to unfavorable planes of the sections than to absence of the fibers in question.

Tecto-thalamic and thalamo-tectal paths, with certain subtectal paths. These interconnections between the dien. cephalon and tectal centers are of prime importance for an understanding of either of these areas. One of the deter- 
mining factors in the relatively great development of both regions in reptiles is the richness of these interrelations. Crossed tecto-thalamic paths are found in part of the supraoptic systems. Attention is directed now to a group of uncrossed tecto-thalamic and thalamo-tectal paths and with these are considered connections with certain closely related subtectal mesencephalic areas. The pertinent literature will be discussed with the tract under consideration.

Before entering upon an account of these fiber systems, the names used for certain associated nuclear groups must be defined in order to obviate confusion with regard to the course and synaptic relations of the tracts. The selection of the name employed here has been based on the writers' understanding of the more usual application of the terminology. No permanent system of nomenclature is advocated and no homologies with other than reptilian forms are implied. In the present account, then, the 'nucleus geniculatus pretectalis' (figs. $6 \mathrm{~B}$, and $7 \mathrm{~A}$ ) is applied to a cell group homologous, it is believed, to the 'geniculato pretettale' of Beccari ('23, figs. 15, 18, and 23), to the similarly termed nucleus in alligator (Huber and Crosby, '26) and in Sphenodon (Cairney, '26). It does not appear to be the homologue of the nucleus geniculatus pretectalis described by Shanklin ('30), but apparently to the group of cells labeled nucleus geniculatus lateralis pars inferior of his figure 7, although not that of figure 6. However, the form relations may be different in Chameleon, or the nucleus larger. At the base of the cephalic end of the tectum is a nuclear mass to which various observers have given the names of nucleus lentiformis (de Lange, '13), the nucleo lentiforme del tetto (Beccari, '23, see particularly fig. 23), or nucleus lentiformis mesencephali (Huber and Crosby, '26; Cairney, '26; Shanklin, '30). While an homologous nuclear mass has been recognized in each case, the precise caudal limits have not been established. Thus de Lange and Cairney have carried it caudalward to a position medial and slightly dorsomedial to their nucleus pretectalis. Shanklin called attention to a 
mass of neuropil and seattered cells caudo-dorsal to the mass of the nucleus lentiformis mesencephali (and presumably included in it by the the above observers) which he regards as the nucleus geniculo-pretectalis. He noted also that the area of scattered cells is bounded ventrally and dorsally for a part of its extent and around its medial border by a band of deeply stained, compactly arranged cells which form a cap over the caudal medial portion. This region forms a deeply staining, distinct nuclear mass in certain reptiles and was termed nucleus spiriformis in Varanus griseus, by Edinger ('08). Huber and Crosby identified this cell group in Alligator mississippiensis as the one so named by Edinger without more than brief mention of it. It is not at all probable that this nucleus is comparable to either of the subdivisions of the spiriform nucleus of avian forms, consequently the name is abandoned here. In the reptiles available for study it is not a recognizable portion of the nucleus geniculatus pretectalis, although, of course, with the relations presented it may be in the chameleon. Its differentiation suggests its separation from the nucleus leritiformis mesencephali. It is the probable homologue of the pretectal complex in birds (which is not that of reptiles). For the present no attempt is made to name this nucleus; it is designated merely by the letter $m$ in figure $7 \mathrm{~A}$. The term nucleus pretectalis (fig. $11 \mathrm{D})$ has been applied to so many nuclei in this region in different vertebrates that the name has almost lost any special significance. As here used the term is intended to designate a nearly round cell group dorsal and slightly caudal to the main mass of nucleus geniculatus pretectalis, chiefly lateral and caudal to the nucleus lentiformis mesencephali and lateral (or slightly ventrolateral) to the cell group designated as $m$. This usage is in agreement with that of Edinger ('08, Bd. II, p. 158; also 1899, Tafel III, figs. 1 and 2), de Lange ('13, fig. 14, also seen in table VIII at end of paper), Huber and Crosby ('26, fig. 11), and Cairney ('26, figs. 32 and 38). Beccari ('23) is believed to refer to an homologous nucleus in his account and in figures 18, 20, and 25. 
Tractus tecto-thalamicus et thalamo-tectalis ventrolateralis was described for the alligator by Huber and Crosby ('26), who regarded it as conducting impulses in both directions. They carried it particularly to the medial side of the tectal area, but the present account indicates that many fibers reach the lateral part of the tectum also. The pretectal nuclei and nucleus lentiformis mesencephali receive collaterals and possibly stem fibers of the tract. A special component was traced from nucleus tractus tecto-thalamici cruciati (which was specifically regarded as a part of the lateral geniculate nucleus, see '26, p. 180). The system as a whole was considered of prime importance as an interconnection between the tectum and the lateral geniculate nucleus, and as homologous with a part of the mammlian peduncle of the superior colliculus.

Cairney ('26) described in Sphenodon a tractus tectothalamicus dorsalis which probably includes the tractus tecto-thalamicus ventrolateralis together with several other tecto-thalamic systems. He stated that it is formed by fibers from the nucleus dorsolateralis anterior, the nucleus rotundus and both parts of the lateral geniculate body. It may possibly receive a few fibers from the nucleus dorsomedialis anterior, but these do not constitute an obvious component. He traced it to the general afferent layer of the tectum and found it also in relation with the nucleus pretectalis, the nucleus lentiformis mesencephali, and the geniculatum pretectale.

Recently, Shanklin ('30) described tracts in the chameleon which, while designated differently, conform very satisfactorily with the earlier accounts of this system. In Chameleon Shanklin described a tractus geniculo-tectalis anterior, a tractus geniculo-tectalis intermedius, and a tractus geniculotectalis posterior. The first mentioned tract arises from his nucleus geniculatus inferior, the homologue of the nucleus tractus tecto-thalamici cruciatus found in association with the lateral geniculate nucleus in the alligator; the tract is homologous with the special portion of the tractus tecto-thal- 
amicus ventrolateralis described in Alligator. The intermediate geniculate tract is the main bundle of the tractus tecto-thalamicus ventrolateralis described for the alligator. The tractus geniculo-tectalis posterior of Shanklin, which arises from the caudal end of the ventral part of the nucleus geniculatus lateralis in the Chameleon was not recognized in the alligator as a separate tract. Possibly it is represented by the caudal part of the tractus tecto-thalamicus ventrolateralis, for in the alligator the tract arises from the whole extent of the nucleus geniculatus lateralis pars ventralis, but the homology is very uncertain.

Turning, now, to a consideration of the fiber systems in the material available for study, it is clear that while the evidence is confirmatory, important details as to the tectal termination of the tracts can be added. In Anolis the anterior portion of the tractus tecto-thalamicus ventrolateralis (fig. $6 \mathrm{~A})$ arising from the nucleus tractus tecto-thalamici cruciati can be traced caudalward to the stratum fibrosum et griseum superficiale, entering all three white layers and the outer part of the stratum griseum centrale. It is probably thalamo-tectal in its direction of conduction.

The main or intermediate mass of the tractus tecto-thalamicus et thalamo tectalis ventrolateralis (tractus geniculotectalis intermedius of Shanklin) carries fibers which are partly thalamo- or geniculo-tectal in character, but largely tecto-geniculate. Traced by the usual path from the dorsal and medial side of the lateral geniculate, pars ventralis of the nucleus, they swing caudalward and dorsalward. Part of the fibers enter the more cephalic end of the tectum and reach the stratum fibrosum et griseum superficiale, distributing both medially and laterally, more particularly though not exclusively through its deep layer and stratum griseum centrale (peripheral portion). These fibers are largely thalamoor geniculo-tectal. They come especially from the more dorsal part of the nuclear complex and include fibers from the nucleus geniculatus lateralis pars dorsalis. The major portion of this intermediate portion of the ventrolateral tecto- 
thalamic et thalamo-tectal tract becomes continuous with the cephalic end of the stratum album centrale. This is the tecto-thalamic or tecto-geniculate portion of the tract. Fibers enter this tract from cells of the stratum griseum centrale as is illustrated in $Q$ in figure 5. It is an important discharge path from the tectum, terminating in the homologue of the mammalian nucleus geniculatus lateralis pars ventralis. From this nucleus connections with lower centers are affected through the tractus geniculatus descendens.

A quite small path of fine, darkly staining fibers is impregnated in the silver material connecting the caudal end of the pars ventralis of the lateral geniculate nucleus with the white layers of the stratum fibrosum et griseum superficiale (fig. $7 \mathrm{~A}$ ). These fine fibers may or may not represent the tractus geniculo-tectalis posterior of Shanklin, but in silver preparations in which the medullated and the non-medullated fibers are impregnated the interconnections between the pars ventralis of the lateral geniculate and the tectum form a continuous band (although varying in density and staining at different levels) as was seen also in the alligator. Where only medullated fibers stained, no doubt such connections might appear as separate bundles. In their course these most caudal fibers follow along the side of the pars dorsalis of the ventral supraoptic decussation. Associated with these bundles of the tractus tecto-thalamicus et thalamo-tectalis ventrolateralis, concerned with interconnecting the nucleus geniculatus lateralis pars ventralis and its associated gray with the tectum are fibers relating these areas to certain pretectal and subtectal centers. In tracing the tract in question from the geniculate nucleus toward the tectum, fibers enter and leave the anterior and intermediate parts of the tract in the region of the nucleus lentiformis mesencephali (which the bundle crosses in part). This nucleus then serves as a way station for impulses between the tectum and the abovedescribed tectal areas. Similar relations are established with nucleus pretectalis, this being supplied particularly from the most caudal third (intermediate and chiefly caudal part) 
of this system. Fibers of the system are seen in relation with the nucleus geniculatus pretectalis. They come into relation with the intermediate and perhaps the caudal part of this nucleus in lizards as Cairney found to be the case in Sphenedon, but it has not been possible in the material in hand to establish the direction of conduction. The other lizards available for study add nothing further to the account given above for Anolis. The tracts are particularly well impregnated in the horned toad, where they follow the pattern just described.

The series of alligator brains on reconsideration yielded the same results as those described in the 1926 paper and which are in essential agreement with the above account. It was possible to trace the tractus tecto-thalamicus ventrolateralis into the stratum fibrosum et griseum superficiale and the peripheral part of the stratum griseum centrale, while fibers were added to it from the deeper stratum album centrale.

In the turtle the efferent fibers of the tectum are in part intermingled with the stratum griseum centrale. The fibers of the ventrolateral tecto-thalamic tract (figs. $8 \mathrm{~B}$, and 9 A) are continuous with the more superficial portion of the efferent layer. The extent of their origin from the midbrain roof is indicated in figure $9 \mathrm{~A}$. Thus continuity with efferent tectal fibers is demonstrable in all the turtle material. The connection with the fibrous layer of the stratum griseum superficiale can be seen also.

In snakes, such as Natrix and Python, the connections of the main ventrolateral tecto-thalamic and thalamo-tectal tract with the superficial and particularly with the deep efferent tectal layers is very evident in the sagittal series. Just medial to this swings dorsocaudalward the more cephalic portion of the bundle together with the fibers of the tractus tecto-thalamicus cruciatus and still farther medial the dorsal supraoptic system.

Tractus tecto-thalamicus (et thalamo-tectalis) dorsolateralis (not illustrated, Huber and Crosby, '26, fig. 20) will 
now be given consideration. This is merely an adjunct to the tractus tecto-thalamicus et thalamo-tectalis just described. Often it is not differentiable from the remainder of that fiber system. In the alligator and in certain of the lizards, such as Anolis, it can be seen as a distinct little bundle arising from the lateral part of the nucleus dorsolateralis anterior. In these forms it can be observed to swing dorsolateralward in order to join the inner border of the tractus tecto-thalamicus et thalamo-tectalis ventrolateralis and to pass to the tectum along with this composite bundle. It is sufficiently discrete, however, to permit tracing it as distinct from other fascicles of the system. This tractus thalamo-tectalis (et tecto-thalamicus ?) dorsolateralis can be traced to the medial portion of the tectal wall, to the region of the stratum fibrosum et griseum superficiale and possibly to the outer part of the stratum griseum centrale. Its connection with the stratum album has not been demonstrated beyond question. So far as the material indicates, the tract appears to be largely an afferent one with respect to the tectum, thus chiefly thalamotectal. In reptiles other than those just considered the bundles from the comparable diencephalic areas could be seen to join the tractus tecto-thalamicus et thalamo-tectalis ventrolateralis, but beyond that point could not be traced independently. Cairney ('26) found fascicles joining the homologous bundle in Sphenedon from the nucleus dorsolateralis anterior.

Tractus tecto-thalamicus et thalamo-tectalis dorsomedialis anterior was described in the alligator by Huber and Crosby ('26) and included in the tractus tecto-thalamicus ventralis of Cairney ('26). It is homologous, at least in part, to the tractus tecto-thalamicus of Edinger (1899) and de Lange ('13, as described on p. 102), and probably to that of Beccari ('23, fig. 15). It has been described recently by Shanklin ('30) under the name of the tractus rotundo-tectalis. With this tract, in Chameleon, are fibers to various subtectal and tegmental centers (tractus rotundo-geniculo-pretectalis and tractus rotundo-mesencephalicus profundus of Shanklin). This observer also describes a tractus tecto-rotundus to more cephalic parts of the tectum. 
Certain particularly favorable planes for the study of this system are found in the sagittal and frontal series of the brains of those turtles available for study. These are illustrated in figures $11 \mathrm{C}$ and $\mathrm{D}$. Reference to figure $11 \mathrm{D}$ makes it evident that at their origin from the nucleus rotundus and its surrounding gray the tectal paths divide into a caudal and cephalic portion. For convenience the caudal portion will be considered first, since this is the portion to which reference was made under the name tractus tecto-thalamicus dorsomedialis anterior. In all reptiles studied, including the turtles, this tract runs almost directly caudolateralward from nucleus rotundus and nucleus medialis posterior to a position near the optic tract where it meets the dorsal part of the ventral supraoptic decussation with which it courses dorsocaudalward. A few of its fibers reach the stratum fibrosum et griseum superficiale and adjoining stratum griseum centrale, but the majority of them become continuous with the stratum album centrale and the deeper part of the stratum griseum centrale in turtles. It is considered then as largely efferent with respect to the tectum. Within the tectal region the afferent fibers course dorsalward into the dorsal regions of the tectum. It is significant that these fibers from the tectum to the nucleus rotundus and its adjoining gray come from the more caudal portion of the tectum, not far from those regions which receive secondary ascending bulbar and spinal fibers. The tractus tecto-thalamicus et thalamo-tectalis anterior (or tractus tecto-rotundus et rotundo-tectalis, if that name be preferred) carries with it fibers which come into relation, either as collaterals or as stem fibers, with the nucleus geniculatus pretectalis of Beccari, other bundles accompanying the tract turn caudalward without entering the tectal region and distribute in the tegmental region. These constitute the homologue of the tractus rotundo-mesencephalicus profundus of Shanklin, with which this account is not concerned. Also with this tract run fibers related to the nucleus pretectalis. 
In addition to this connection between the more caudal portion of the tectum and the nucleus rotundus and associated gray, there are bundles which turn forward from the nucleus rotundus to reach the cephalic parts of the tectum. In their course they parallel that of the tractus tecto-thalamicus (et thalamo-tectalis) ventrolateralis and probably are included by Cairney ('26) in his account of the homologue of the latter tract in which he includes fibers from the nucleus rotundus. They are comparable to the tractus tecto-rotundus in Chameleon (Shanklin, '30).

In the turtle such cephalic fibers of the anterior dorsomedial tecto-thalamic tract swing directly across the field (fig. $11 \mathrm{D}$ ) and become continuous with the efferent bundles in the stratum griseum centrale. But few fibers of the cephalic part of the tract have been traced with certainty to the afferent tectal layers. So far as the evidence goes at present, this is largely a tecto-thalamic system.

The conditions described in the preceding paragraph for the turtle find substantiation in the material of lizards available for study, particularly in the pyridine-silver series of Anolis. Only one point deserves further attention. As has been stated previously, in the lizard the efferent tectal fibers turn into the stratum album centrale before leaving the tectal region; consequently, the efferent portions of both the caudal and cephalic components of the tractus tecto-thalamicus et thalamo-tectalis dorsomedialis anterior are continuous with the stratum album centrale. In the American alligator the caudal part of the tract under consideration is entirely similar to that described for lizards and turtles. It sends certain fibers to the stratum fibrosum et griseum, but the majority of its fibers become continuous with the bundles in the stratum griseum centrale and the outer part of the stratum album centrale, indicating that the character of this tract is not exclusively but largely tecto-thalamic. It has not been possible as yet to trace conclusively the cephalic part of the tract to the tectum in the alligator, but in all probability it is present in relations entirely comparable to those described for turtles. 
In snakes cephalic and caudal parts of the tractus tectothalamicus and thalamo-tectalis dorsomedialis anterior can be demonstrated; they are particularly clear in certain preparations of the copperhead, Agkistrodon mokasen, available for study.

A tractus tecto-thalamicus dorsomedialis posterior (not illustrated) was described for the alligator by Huber and Crosby ('26, fig. 23). This connected the tectal area with the gray immediately ventral to the posterior commissure and dorsal to the caudal end of the nucleus rotundus and its adjoining nuclear masses. The writers prefer to postpone for a future discussion the homologies of the nuclear masses in this region. The fibers reaching this area swing directly ventralward from the stratum album centrale until they have reached the region immediately below the posterior commissure. Here, in the material of the alligator, fibers of this system turn rather sharply medialward. This region is a region of passage for many fiber bundles. Through here in addition to the bundles under discussion are other fibers to the tectal region, such as bundles of the dorsal supraoptic system. Fibers at right angles to these are in part fascicles of the tractus tecto-thalamicus dorsomedialis posterior, but include descending fibers as well, in part fascicles of the tractus geniculatus pretectalis descendens. It is difficult to determine the size or extent of the tractus tecto-thalamicus dorsomedialis posterior through such a maze of fibers. It is clearly evident in the alligator and demonstrable in the material of the horned toad, but although other reptilian preparations available for study strongly suggest its presence, the evidence of such presence is not conclusive.

Tractus tecto-thalamicus medialis makes its appearance in planes through the most cephalic end of the posterior commissure. It appears as a small band just dorsal to the nucleus rotundus in the region of the nucleus medialis anterior. It is in relation with this nucleus and with the nuclei of the midline medial to the nucleus rotundus. The tract increases somewhat in size followed caudalward, being added 
to by fibers from the nucleus medialis posterior, joins the tractus tecto-thalamicus dorsomedialis anterior on its dorsocaudal side, and apparently accompanies it to the tectum. In part it becomes continuous with the stratum album centrale. Whether or not it has connections with the superficial tectal strata in Anolis it has thus far not been possible to determine positively.

In certain reptiles, as, for example, in certain turtles, it has not been possible to differentiate this as a separate tract, but fibers from this nucleus join the tractus tecto-thalamicus dorsomedialis anterior. However, in Alligator the tract (fig. $7 \mathrm{~B})$ is quite distinct and separable from the tractus tectothalamicus et thalamo-tectalis dorsomedialis and is slightly more closely related, at least through a part of its course, with the tractus tecto-thalamicus dorsomedialis posterior, but in all essentials it presents the same relations.

A tractus tecto-reuniens was figured by Edinger (1899, Tafel 1, fig. 1, unlabeled), but he was unable to follow it to the tectum with certainty, although he conjectured that it terminated there. Probably such fibers were figured by de Lange ('13) in figures 25 and 26, under the name of the tecto-thalamic tract.

In the alligator, from the large nucleus reuniens, there may be observed a bundle of fibers which can be traced lateralward and caudalward across the field to a position medial to the ventral part of the ventral supraoptic decussation. Here many of the fascicles are so intermingled with cells of a nuclear cell mass variously designated as geniculatum internum of Bellonci (1888), nucleo $\delta$ of Beccari ('23), nucleus Z of Huber and Crosby ('26), that it is impossible to determine to what extent a synapse occurs. Certain of the fibers, particularly the more cephalic ones, are believed to pass to the deeper portion of the tectal regions, but this requires verification.

In the lizards available for study and in certain turtles little if any nucleus is found in the midline, but a nucleus reuniens may be developed to a condition approaching that in Alligator (see figure of Chelone midas, de Lange, '13). 
However, on either side of the midline, ventromedial to the nucleus rotundus, there may be noted a differentiated mass of gray, larger in the turtle and smaller in the lizard (Anolis) from which fibers join the caudal part of the tractus tectothalamicus (et thalamo-tectalis) dorsomedialis anterior, and probably reach the tectum with it. Such fibers are continuous with a fiber bundle which bears the same relation to the geniculatum internum of Bellonci as does the more caudal portion of the tractus tecto-reuniens to the homologous nuclear mass in alligator.

To the nucleus geniculatus pretectalis of Beccari appear to come fibers from the stratum album centrale of the tectum in company with the tractus tecto-thalamicus dorsomedialis anterior. The size of this tract, which constitutes a tecto-pretecto-geniculate system, varies with the degree of the development of the nucleus. For example, it is more evident in the sections of Anolis than in those of the young alligator. However, in no case has it been possible to trace terminations of these fibers around the cells of the nucleus and the possibility is not excluded that they may represent fibers of passage. This bundle probably constitutes an efferent tract for the tectum through a tractus tecto-geniculo-pretectalis and then to lower centers by way of the fasciculus pretectalis descendens. Accompanying these fibers, but passing to a deeper portion of the stratum fibrosum et griseum superficiale are fine fibers which appear to arise from the nucleus geniculatus pretectalis. However, it has not been possible to trace neuraxes of the cells of this nucleus into the tract and with the presence of so many tracts the possibility is not excluded that these may represent fibers of passage.

The nucleus lentiformis mesencephali situated at the base of the tectum is in intimate relation with the optic tract from which it appears to receive at least collaterals. This is the region of passage of the brachium tecti medialis, to which reference has been made earlier. Short fibers between both the deep and superficial regions (medial and lateral) of the tectum and the nucleus lenticularis mesencephali can be seen 
in many of the brains studied, but it is impossible to determine at present what proportion of these constitute fibers of passage.

The pretectal nucleus lies along the path of the decussatio supraoptica dorsalis and is in intimate and probably synaptic relations with the tractus tecto-thalamicus dorsomedialis anterior (interconnected by way of this path with the nucleus rotundus and the tectum) and its associated fiber bundle, the decussatio supraoptica ventralis. It is also in relation with tractus tecto-thalamicus (et thalamo-tectalis) ventrolateralis. Therefore, it is difficult, owing to the richness of fibers of passage, to determine the pretectal-tectal connections. Many of them undoubtedly join tectalward running tracts, and the pretectal nucleus probably receives many collaterals from efferent tectal systems which pass near or through it. However, from the lateral border of the nucleus very fine fibers pass dorsolateralward to the stratum fibrosum et griseum superficiale (fig. $7 \mathrm{~A}$ ), some of which can be traced almost to the dorsal surface. From stratum album centrale, on both the lateral and medial walls, fibers enter the pretectal complex, constituting a tecto-pretectal path (fig. 11). The above account is based primarily on the presentations in Anolis, Alligator mississippiensis, and turtles, such as Chelhydra serpentina and Sternotherus odoratus. Nucleus lateralis profundus mesencephali also receives fibers from the tectum.

Certain diencephalic and mesencephalic periventricular connections with the tectum. Along the periventricular region of the diencephalon and mesencephalon, to some extent intermingled with, but largely internal to the periventricular gray, appear many strands of fine, mainly non-medullated fibers which, taken together, constitute a periventricular fiber system (figs. 6, 7, 8 B, 9, 10, and $12 \mathrm{~A}$ ). This system is composed of many constituent paths, with widely different functions and relations, and the system as a whole has never been adequately analyzed, although certain of its components have been discussed (Huber and Crosby, '26; Cairney, '26; Shanklin, '30). A comprehensive analysis of this system presents a problem 
in itself and is outside of the scope of the present communication, but attention is called to certain tectal components of the system.

Fibers from the nucleus dorsomedialis anterior and nucleus dorsolateralis anterior probably contribute and certainly receive short internuclear fibers of this system. Such fibers in part relate these dorsal thalamic nuclei with each other and with the area below the sulcus medius. From these regions, a few bundles at a time, fibers of the diencephalic periventricular system swing to the region of the nucleus geniculatus lateralis pars ventralis. Those from the nuclei above the sulcus medius can be traced no farther in most of the lizard and turtle material studied. Whether they may pass through this nucleus to join tectal paths or arise or terminate (or both) within it cannot be determined for the forms mentioned. These results coincide with those described for Chameleon by Shanklin ('30). In Alligator the great lateral extension of the ventricle permits a somewhat more complete analysis of the dorsal part of these fibers in this reptile, particularly those bundles from the nucleus dorsomedialis anterior and nucleus dorsolateralis anterior. As was stated in the earlier description of this system (Huber and Crosby, '26), fibers can be traced from the medial side of the nucleus dorsomedialis anterior around its ventral border and then lateralward toward the tecto-thalamic system. For a considerable part of their course lateralward many of the bundles are in close relation to the dorsal wall of the lateral extension of the ventricle, consequently effectively separated from overlying: fiber systems. They appear dorsal to the geniculatus descendens and join the more anterior part of the ventrolateral tecto-thalamic tract and its accompanying tractus tecto-thalamicus cruciatus. This fiber system as it courses from the medial to the lateral part of the diencephalon presents the form of a thin horizontal sheet of many parallel fibers, in transverse planes, so cut that in many of the sections thin bands stretch from the midline to a point near their entrance to the tecto-thalamic system, and sometimes such a band can 
be seen to course dorsally into direct continuity with this system. These fibers are accompanied in their course by short internuclear fibers, and certain fibers may be seen entering the nucleus geniculatus pars ventralis. It must be appreciated that so soon as the fascicles have joined the tectothalamic systems they are indistinguishable from the bundles of the system, and the possibility that they may turn out of the bundle to synapse with gray along their course cannot be excluded. However, the probabilities are that they reach either the nucleus pretectalis or the tectum (or both). Another portion of the diencephalic periventricular system concerned with interconnecting thalamic and tectal centers deserves consideration. A plexus of fibers extends from the tectum, forward near the midline beneath the posterior commissure. This plexus is impregnated in representative turtles, lizards, and snakes, and probably is present in all reptiles. This plexus is related to the nucleus medialis anterior, the nucleus dorsomedialis anterior, to the gray extending medial and ventromedial to the nucleus rotundus, to capsular cells and fibers at least of the nucleus rotundus, to nucleus medialis posterior, and other gray of the region. In certain instances it is possible to trace these fibers for long distances, many of them may be internuclear. Favorable planes in various reptiles, for example, horned toad, indicate that certain of these nuclei, particularly the nucleus medialis anterior and the nucleus dorsomedialis anterior have fibers which can be traced into the tectum entering its periventricular layer. Since the number of demonstrable periventricular cells which send neuraxes into the periventricular layer appears to be relatively very small, these probably constitute a thalamotectal system.

Fibers from the preoptic and hypothalamic areas run dorsalward in the diencephalic area. Certain of the more cephalic of these bundles swing across the field, turning dorsolateralward below the sulcus medius and join the ventrolateral tecto-thalamic system and its associated fibers. Neither their origin nor destination is known at present. 
A rich periventricular plexus of fibers relates the tectal periventricular regions with the gray nearest the ventricle in the tegmental region of the mesencephalon. Among these bundles fibers can be traced to the Edinger-Westphal and other oculomotor nuclei, others swing back toward the trochlear nucleus. There exists a rich periventricular plexus extending from the tectal region caudalward under the cerebellum where fibers of the system lie in close relation with the commissure at its base and ventral to this region become continuous with the periventricular system of the medulla. The evidence from Golgi preparations, both those of the chameleon studied by Ramón (1896) and those of the turtle (fig. 5), indicates that much of this system (at least) is afferent with respect to the tectum. The relations of the inferior colliculus to the optic tectal periventricular system will be considered under a separate heading.

Tractus tecto-striatalis (figs. $8 \mathrm{~B}$, and $9 \mathrm{~A}$ ). Huber and Crosby ('26) for the American alligator described a bundle which separated from the ventral peduncle of the lateral forebrain bundle and coursed caudodorsalward to reach the deep fiber layer of the stratum album centrale of the lateral and more caudal regions of the tectum. An homologous bundle was identified in the chameleon by Shanklin ('30) and also termed tractus strio-tectalis. Its presence in various other reptiles, particularly in the lizards and in the turtles, has been verified. It reaches the caudolateral region of the tectum and extends upward in the outer part of the stratum album centrale toward the dorsal surface. Shanklin ('30) found similar relations in the chameleon. Its relations to this stratum suggest very strongly that this tract should be designated tractus tecto-striatalis, rather than the tractus striotectalis, as has been done here.

Tecto-epithalamic connections. Cairney ('26) demonstrated an habenulo-tectal tract in Sphenodon, carrying it to the tectal areas with his dorsal tecto-thalamic tract (tractus tecto-thalamicus et thalamo-tectalis ventrolateralis of the present account). Shanklin ('30) found fine fibers passing caudal- 
ward from the habenula to the commissural area of the tectum. These fibers are seen most easily in sagittal sections. Figures $11 \mathrm{~A}$ and $11 \mathrm{~B}$ indicate the position of bundles extending forward from the stratum album centrale to the habenula constituting a tecto-habenular tract. These are illustrated for Anolis and Natrix, but the relations found in these forms can be documented for other reptiles; they are particularly clear in certain of the turtles. These fibers of the tractus tecto-habenularis enter the habenula with the bundles of the habenulo-peduncular tract. Associated with them are a few bundles which cross in the most cephalic part of the posterior commissure. These constitute a tractus tecto-habenularis cruciatus in all probability. Either collaterals or stem fibers of this system decussate in the commissura tecti diencephali. These tecto-habenular systems show certain resemblances to those described by Herrick ('17) for Necturus.

Commissura tecti diencephali. Commissura posterior. Commissura colliculi superior. Between the habenular commissure and the cephalic end of the posterior commissure there is evident a narrow band of darkly staining fibers which is believed to correspond to the commissura tecti diencephali (fig. 9 A) described for certain other forms (Herrick, '17). This bundle is very small but deeply stained in Anolis, but it is slightly better developed in certain of the turtles, as Chelhydra serpentina and Sternotherus odoratus. It has not been recognized in the alligator perhaps by reason of the absence of an epiphyseal stalk. It is present in the snakes, such as Natrix. In lizards, turtles, and snakes it interconnects the adjacent gray and in the latter two forms, less clearly for the lizards, it appears to carry fibers coursing with the habenulo-peduncular tracts at their exit from the habenula, presumably belonging to a crossed tecto-habenular system. Continuous with the bundles of the commissura tecti diencephali, but less nearly black in color in the silver preparations, appears the cephalic end of the commissura posterior. This broad commissural band is to a great extent non-tectal in character. Space does not permit a complete discussion 
of the well-known commissural system and its non-tectal components will be considered only where they are concerned with subtectal or pretectal centers frequently referred to in the preceding account. For a description of the non-tectal components of the posterior commissure reference is made to the work of Ramón (1896), de Lange ('13), Ariëns Kappers ('20-'21), Beccari ('23), Huber and Crosby ('26), and Shanklin ('30).

Fibers of the tractus tecto-thalamicus et thalamo-tectalis ventrolateralis with associated tecto-thalamic bundles reach the region slightly ventrolateral to the cephalic border of the posterior commissure. It is believed that certain bundles of this general system cross in the posterior commissure, although as yet it has not been possible to state with certainty which components of this general system decussate in this fashion (fig. $9 \mathrm{~A}$ ). Tecto-habenular fibers cross in its anterior part. From the region of the nucleus posterodorsalis, nucleus geniculatus pretectalis and nuclens lentiformis mesencephali fibers are contributed to the commissure. At about the same level a few bundles sweep across the subtectal region and enter the stratum fibrosum et griseum superficiale on its ventrolateral side (fig. $6 \mathrm{~B}$ ). Following caudalward in the series, posterior commissure fibers are found to reach the nucleus pretectalis and the region $m$ (fig. $7 \mathrm{~A}$ ). The fibers described thus far belong to the ventral part of the posterior commissure. This ventral portion now becomes continuous with bands of fibers crossing dorsal to it and continuous with the stratum album centrale of the two sides below the optic ventricle. This constitutes the so-called dorsal part of the posterior commissure (fig. $7 \mathrm{~A}$ ), which is separated for the very first part of its course from the ventral part, but soon becomes continuous with it. The separation, which is present for only a short distance in the lizards studied and which, according to Shanklin ('30), does not occur in the chameleon, is marked in certain reptiles, as, for example, the American alligator, but even in this form the two parts become continuous. The dorsal part of the posterior commissure is continu- 
ous for a short distance with bands of fibers which interconnect the stratum album centrale of the two sides dorsal to the optic ventricle. This commissure is called either the commissura colliculi superioris (figs. $7 \mathrm{~A}, 9 \mathrm{~B}$, and $10 \mathrm{~B}$ ) (Huber and Crosby, '26; Shanklin, '30) or the commissura tecti (Cairney, '26), and in addition to the fibers mentioned above, carries bundles between the other fiber layers of the optic tectum. For most of its extent the superior collicular commissure is independent of the other commissural systems, since it lies in the roof of the midbrain above the optic ventricle. The preceding account can be documented for other reptiles with certain minor variations as to size and relation of components which do not appear to merit a separate description.

Connections between the optic tectum (superior colliculus) and the inferior colliculus. Attention has been drawn earlier in the present paper to the interrelation between the superior and inferior colliculi and to the fact that the caudal part of the stratum album centrale, in forms such as Anolis, Chrysemys, and Natrix, is continued over its lateral and caudal surfaces in its course toward lower centers (through such paths as tecto-isthmal, tecto-cerebellàr and in part ventral tecto-bulbar). There is indication that occasional fibers turn in to come into relations with its cells. The most striking interrelation between the superior and inferior colliculi is through the periventricular gray layers (see fig. $11 \mathrm{~B}$, indicated but not labeled). The periventricular gray of the optic tectum is continuous partly around the nuclear mass, suggesting a capsule, and is partly continuous with it, while the strands of fibers between the periventricular gray layers which break up into a rich plexus within the inferior collicular nuclear mass. This nucleus appears as if it were a differentiated mass of periventricular gray, but with specific, characteristic connections. The inferior colliculus is connected with the superior colliculus through the fascicles mentioned above and through fibers of the tectal stratum fibrosum periventriculare. In this manner impulses are carried to the cells of the stratum griseum periventriculare. 
Connections of spinal and bulbar centers with the tectal centers. Spino-mesencephalic fibers, suggested by Ariëns Kappers ('20-21) under the name of tractus spino- et bulbomesencephalicus et tectalis were confirmed for Alligator mississippiensis (Huber and Crosby, '26). At the lower level of the medulla it is found in a position just ventral to the spinocerebellar system; followed forward it shifts slightly dorsalward, but remains in a position ventromedial to the nucleus of the descending root of the trigeminal. Near the level of the sensory nucleus of the trigeminal, the spino-mesencephalic system turns inward and forward to distribute in part, together with certain secondary trigeminal fibers and fascicles of the lateral lemniscus, to the optic tectum. The secondary ascending tracts of the trigeminal (sometimes termed the trigeminal lemniscus) arise from the chief sensory nucleus of the opposite side and probably of the same side and the contralateral nucleus of the descending root and swing forward to terminate in part in the tectum together with the components of the spino-mesencephalic and lateral lemniscus which reach this area. These fibers cross the outgoing fibers from the stratum album centrale at their entrance to the tectum and many of the fascicles could not be traced to their termination in the tectum. However, in the alligator, in certain of the turtles, and in several of the lizards, it was possible to trace fibers of this complex into the outer part of the stratum griseum centrale, which is believed to receive certain other afferent fibers. Some evidence of a termination of these secondary ascending systems within the stratum fibrosum et griseum superficiale was obtained; in part this is by unmedullated collaterals. The systems under discussion enter the caudal and lateral portion of the tectum and terminate there in relation to cells of origin of certain tecto-thalamic systems, as, for example, the caudal part of the tractus tecto-thalamicus (et thalamo-tectalis dorsomedialis anterior) (see discussion, p. 132). The above account is based primarily on the alligator (Huber and Crosby, '26), figures illustrating the course of these paths may be found in this communication. 
Tecto-cerebellar systems. Tecto-cerebellar tracts, occasionally an elaborate system of interconnection between the tectum and the cerebellum, have been described for various vertebrates. In many forms these arise from the inferior colliculus. An uncrossed tecto-cerebellar tract was traced in Chrysemys as far as the granular layer of the cerebellum by Huber and Crosby ('26). Recently, Shanklin ('30) described a tecto-cerebellar tract in the chameleon, which carried crossed and uncrossed fibers. A study of lizard material available substantiates Shanklin's account of this crossed and uncrossed tract. The uncrossed bundle is very small, the crossed portion slightly larger. New and better Weigert preparations of Chrysemys show these paths clearly. The conditions in this reptile are probably typical for reptiles, although as yet the tracts have not been identified in all of the material available for study.

Since a series of papers on cerebellar connections is in process of preparation in this laboratory, further elaboration of this system will not be undertaken here. A very brief account of the tracts as they appear in Chrysemys will be presented.

Swinging ventralward from the stratum album centrale and the deeper part of the stratum griseum centrale (in lizards from the stratum album centrale) fibers pass caudal to the inferior colliculus and then in part enter the commissure at the base of the cerebellum where they decussate, other fibers enter the cerebellum on the same side. The uncrossed fibers enter the granular layer, but whether they terminate there or pass into the molecular layer as climbing fibers, as is conjectured to be the case in certain vertebrates, cannot be stated now. The tecto-cerebellar system is in close relation on its lateral side with the isthmo-tectal and tecto-isthmal paths and with the nucleus isthmi. A few practically unstained fibers can be traced in Weigert preparations between the cerebellum and the tectal regions. These enter the stratum fibrosum et griseum superficiale; the question of the existence of a cerebello-tectal path is open for discussion. Fibers from the mesencephalic root of the trigeminal nerve have been traced 
into the cerebellar commissure. Joining the tecto-cerebellar path, largely by swinging between the fascicles of this root, are fibers from the inferior colliculus.

Isthmo-tectal and tecto-isthmal comections. These connections (fig. $12 \mathrm{E}$ ) are found in Anolis in substantially the same relations as previously described for the alligator (Huber and Crosby, '26). An isthmo-tectal tract was mentioned by Ariëns Kappers ('20-'21). The description given here and earlier agrees with that of Larsell ('24) for the frog. Recently such tracts have been figured for Chameleon (Shanklin, '30). This latter observer described the bundle as passing into the deeper layer (stratum album centrale) of the tectum. This constitutes the main portion in Anolis and is regarded as predominantly tecto-isthmal. The bundle runs forward, dorsalward, and slightly medialward from the upper part of the nuclei, lying in close relation to the isthmal bundle connecting with the inferior colliculus. Outside of this main mass of fibers are observed bundles in certain silver preparations which distribute more peripherally in the tectal regions and are probably isthmo-tectal in character. These connections have been found in various reptiles.

Tractus nigro-tectalis; tractus tecto-nigralis. Along the lateral wall of the mesencephalon, in planes through the red nucleus and the oculomotor nucleus is to be noted a group of scattered, large cells. These cells receive terminal fibers of the lateral forebrain bundle. Shanklin ('30) termed them nucleus entopeduncularis; Beccari ('23) labeled them 'Sost. nera?' It is to be remembered that in vertebrates generally the lenticular portion of the striatum (or its forerunner) is more or less continuous with the scattered cells which extend along the course of the ventral peduncle of the lateral forebrain bundle. In mammals the major portion of this submammalian ventral peduncle becomes the ansa lenticularis and the entopeduncular gray is represented by sereral nuclear masses in the course of the bundle. Among such is the mammalian entopeduncular nucleus represented in part by the reptilian nucleus decussationis supraopticae dorsalis 
and having similar connections. Another portion becomes the mammalian substantia nigra and it is the reptilian equivalent of this portion which lies along the ventrolateral wall of the mesencephalon as described above (figs. $9 \mathrm{~B}$ and $10 \mathrm{~A}$ ). The further evidence for this interpretation of the nuclear mass will be presented later. At this point certain tecto-nigral and nigro-tectal tracts will be described, which correspond in a general way to those of certain mammals (Tsai, '25; Rioch, '29).

Tractus nigro-tectalis (fig. 9 B) swings directly dorsalward from the upper pole and the lateral surface of the nucleus along the brain surface and enters the tectum internal to the optic tract fibers. It has been traced to the lateral region of stratum fibrosum et griseum superficiale.

Tractus tecto-nigralis (fig. 9 B) swings downward and lateralward from the stratum album centrale, internal to the tractus tecto-bulbaris ventralis, to reach the dorsomedial border of the here-termed substantia nigra. In reality and in a certain sense this constitutes a lateral portion of a tectotegmental system. The above account is based on Anolis. Similar connections have been observed in the horned toad, except that the tractus nigro-tectalis receives some fascicles from the medial as well as from the lateral surface of the substantia nigra. Nigro-tectal and tecto-nigral fibers are present in the alligator, the latter connection being particularly clear. The connections of the system in the turtle are similar to those described for Anolis. In snakes, such as Natrix, the tecto-nigral path is fairly large and easily identified. The nigro-tectal path is not as clear, but the evidence for a path from the dorsal and medial surface of the nucleus into the stratum fibrosum et griseum superficiale is quite satisfactory.

Tecto-bulbar and related efferent systems. In the following account the usual terminology is employed, namely, that a tract is designated a crossed tecto-bulbar tract if it decussates in the region below the ventricle and an uncrossed tract if it passes caudalward without such decussation. This does not 
take account of possible crossing in the superior collicular or tectal commissures. That a certain amount of such crossing occurs, varying with the development of the tectal commissure in the form under consideration, is certain. Since at present it is not possible to state whether those fibers which cross above the ventricle remain uncrossed below it, such tectal decussation as yet cannot be taken into account in the nomenclature.

The tractus tecto-bulbaris dorsalis cruciatus was described for the chameleon by Ramón (1896) and Shanklin ('30); for various other reptiles by de Lange ('13) and Ariëns Kappers ('20-'21); for the American alligator (Huber and Crosby, '26). de Lange, Ariëns Kappers, Huber and Crosby, Shanklin, and others have described the uncrossed path. The tractus tecto-bulbaris intermedius non-cruciatus and tractus tectotegmentalis were described by Shanklin ('30). The tractus tecto-bulbaris ventralis is the fasciculo externo of Ramon (1896). The crossed and uncrossed components of this tract were described by de Lange and have been recognized by various other students of the reptilian mesencephalon.

Tractus tecto-bulbaris dorsalis (figs. $9 \mathrm{~B}, 10 \mathrm{~A}$ and B) arises from the optic tectum for a considerable part of its extent. The fibers sweep dorsalward as a continuation of the deepest portion of the stratum album centrale just external to the periventricular gray, and after a partial decussation beneath the medial longitudinal fasciculus and in the dorsal part of the tegmental decussation they accompany that bundle caudalward. The uncrossed path takes up a position slightly dorsalward, lateral, then slightly ventrolateral to the median longitudinal fasciculus. It could be followed into the medulla where it undoubtedly supplies efferent centers, but the details of its distribution were not ascertained. In all of the reptiles studied the crossed dorsal tecto-bulbar path is easily identified, particularly at the level of its decussation (figs. $9 \mathrm{~B}$ and $10 \mathrm{~A}$ and $\mathrm{B}$ ). It was not possible in some preparations to identify the uncrossed path, but it was found not only in Anolis, but in certain other lizards, in alligator, in turtles, 
and in snakes, such as Natrix, and it probably is present in all reptiles. The question as to whether or not the dorsal tecto-bulbar tract may arise from contralateral as well as homolateral tectal areas, crossing in the tectal or superior collicular commissure, is not readily answered except through experimental proof. In Anolis and in Alligator the tract appears to arise, at least largely, from the homolateral tectal region. However, in Anolis in the caudal tectal region a few fibers were traceable across the midline. In certain snakes, as Natrix, there appears to be a larger group of contralateral fibers entering the dorsal tecto-bulbar tract after decussation in the superior collicular commissure. However, such statements require experimental verification.

Tractus tecto-bulbaris intermedius (non-cruciatus, figs. $9 \mathrm{~B}$, and $10 \mathrm{~A}$ and $\mathrm{B}$ ) is a descending bundle from the stratum album centrale which swings ventralward and then caudalward through the ventral portion of the tegmental region, slightly ventrolateral to the median longitudinal fasciculus. It can be traced through the medulla in this same relative position, but apparently gradually diminishes in size. In Natrix the tectal commissure contributes to this tract. The relations are found to be much the same in all of the reptilian material studied. Accompanying this tract are many fibers of the stratum album centrale which, swinging down through the radiation of Meynert, distribute to much of the tegmentum. These, taken together, constitute a tecto-tegmental system (fig. $10 \mathrm{~A}$ ). Special bundles of this system immediately external to the fibers passing down to the dorsal tegmental decussation come into relation with the red nucleus. Other fibers reach this nucleus after crossing in the dorsal tegmental decussation. These bundles are believed to supply crossed and uncrossed tecto-rubral tracts. Certain of the most caudal fibers of the tecto-tegmental system appear to be crossed in the most caudal part of the tectal commissure; in fact, in Natrix there is a suggestion that they are accompanied by intertegmental fibers. 
Descending from the deeper layers of the stratum album centrale with the tractus tecto-bulbaris dorsalis cruciatus are fibers which enter the Edinger-Westphal nucleus. Certain fibers accompanying the tract through the dorsal tegmental deeussation appear to turn dorsalward and are believed to enter this nucleus also, but the evidence for this is not conclusive. Other fibers of this system reach the somatic efferent nuclei of the oculomotor farther caudalward. Such fibers are both crossed and uncrossed within the tegmentum. These constitute tecto-oculomotor tracts. They are illustrated in several figures (figs. $9 \mathrm{~B}$, and 10 ).

Tractus tecto-bulbaris ventralis (figs. $9 \mathrm{~B}$, and $10 \mathrm{~B}$ ) has both a crossed and an uncrossed component. The decussation of the crossed path occurs in the ventral part of the field toward the caudal portion of the midbrain, the path coursing candalward in a ventrolateral position, intermingled to some extent with other fibers of passage. Many fibers of this system leave the tectum without decussation in the tectal commissure. However, in certain reptiles, particularly in certain snakes, fibers from contralateral tectal areas, decussating within the tectum, are added.

\section{DISCUSSION AND SUMMARY}

The preceding account evidences the complexity of structure of the optic tectum or superior collicular region of the midbrain roof as concerns stratification, relative size, and richness of demonstrable fiber connections. Among the reptiles studied, the stratification presents its highest differentiation in certain lizards in which conditions resembling those described years ago by Ramón can be verified readily. While such a highly specialized pattern is demonstrable in certain lizards, if these forms are taken as a basis for comparison of higher and lower reptiles, the observations here recorded show that the layering becomes relatively less distinct in such lizards as gila monster and Varanus, and in the alligator, though the turtles show a variable differentiation depending on the form studied, but always less evident than in the 
lizards; it is still less evident in snakes, especially in the outer parts. Since the layering of Ramón is not applicable to all reptilian forms, it seemed advisable, for the present report, to adopt a more comprehensive nomenclature capable of application to all the forms studied; consequently, the optic tectum has been subdivided into six fundamental strata, exclusive of the ependyma, namely: 1) stratum opticum, carrying many of the incoming optic nerve fibers; 2) stratum fibrosum et griseum superficiale, primarily a region of reception of afferent tectal paths; 3) stratum griseum centrale, composed chiefly of cells of origin of efferent tectal paths and in many forms carrying a part of the efferent fiber system; 4) stratum album centrale, the main efferent pathway of the optic tectum and the chief avenue of superior collicular commissural fibers; 5) stratum griseum periventriculare, composed of cells the neuraxes of which give rise to efferent tectal fibers and the dendrites of which in radiating toward the tectal surface and toward the ventricle give opportunity for synaptic relation in all of the strata;6) stratum fibrosum periventriculare, a region rich in fibers (chiefly of other than tectal origin, except for dendritic branches) which relate the various periventricular regions of the diencephalon, mesencephalon, and medulla and the inferior colliculus, with the optic tectal areas.

The optic tectum of reptiles, exclusive of its subtectal attachment, is embraced by optic tract fibers, which course at or near its periphery (pp. 84-91). But while the incoming bundles occupy this superficial position over nearly the entire extent, terminal bundles swing in to form arborizations with the dendrites of tectal cells throughout the stratum fibrosum et griseum superficiale, such synaptic connections occurring chiefly in the fibrous layer in forms such as Anolis where the stratification is regular. Such synaptic relations afford the anatomic basis for many of the more generally accepted optic reflex paths. They also give basis for the reinforcement of impulses, attention to which was drawn by Ramón. This observer also traced neuraxes of periventricular cells into 
the stratum opticum. The Golgi material available confirms the presence of such neuraxes in the region of this stratum, but none have been carried out of the tectum with the optic tract. Their destination has not been determined.

The dorsal supraoptic system, so far as related to the tectum, is to be regarded as partly afferent and partly efferent, consisting of a variable number of commissural fibers which in all probability carry with them short decussating and nondecussating tecto-thalamic and thalamo-tectal fibers. This system, morphologically and functionally considered, includes the tractus tecto-thalamicus et thalamo-tectalis cruciatus-a fiber system related to a differentiated portion of the lateral geniculate complex.

The ventral supraoptic system consists of a dorsal and a ventral portion. The dorsal portion includes commissural fibers between the optic tectal regions and fibers into the stratum fibrosum et griseum superficiale and receives fibers from the stratum album centrale. The relations of the ventral portion are more complex in that in its course it lies in relation with a large nuclear mass (geniculatum internum, Bellonci, 1888; nucleus $\delta$ of Beccari, '23; and nucleus $\mathrm{Z}$ of Huber and Crosby, '26) in which the amount of synapse of this system appears variable. Fibers of this ventral portion supplemented by those from the nucleus pass dorsocaudalward to the optic tectum and the inferior colliculus. In certain reptiles a few bundles are believed to reach nucleus isthmi. In addition to bundles just described as components of the ventral portion of the ventral supraoptic system, there are fibers of this system which pass directly to the optic tectum in company with the dorsal portion of the ventral supraoptie system. Such fibers distribute in part to stratum fibrosum et griseum superficiale and arise in part as a continuation of the stratum album centrale; it is conjectured that such fibers are commissural.

The non-tectal fibrae ansulatae are not included in this discussion. 
The interdependence in development and function of the optic tectal regions and the dorsal thalamus finds ample anatomic basis in the richness of the fiber connections relating these areas, certain of which are represented in supraoptic systems. A considerable number of such connections have been described under the heading of tecto-thalamic and thalamo-tectal paths. No attempt is made to summarize all of the known connections of these systems ; for details the reader is referred to pages 102-115. However, certain functional relations deserve emphasis. In the reptilian thalamus, representatives of dorsal and ventral parts of the lateral geniculate complex, as this is known in mammals, together with certain associated gray, are recognized. Of necessity such centers have intimate relations with the optic tectum. Such relations are established chiefly by the tractus tectothalamicus et thalamo-tectalis ventrolateralis which is supplemented to some extent by the tractus tecto-thalamicus et thalamo-tectalis cruciatus. The tractus tecto-thalamicus et thalamo-tectalis ventrolateralis is a broad sheet of fibers related to the pars ventralis of the lateral geniculate nucleus and its associated gray, through practically the extent of the nucleus, and any subdivision of this fiber system is arbitrary. The tract as a whole carries afferent and efferent fibers with respect to the tectum and in many reptiles it is in relation with nearly all of the tectal area, medially and laterally. The most cephalic fibers of the group are concerned chiefly in interrelating the associated nucleus tractus tecto-thalamici cruciati with the tectum, but the remainder of the sheet of fibers serves to connect the nucleus geniculatus lateralis itself with the optic tectum. Such fibers are both afferent and efferent with reference to the tectum, but predominantly efferent. This is a matter of some importance since the ventral part of the nucleus serves more particularly as a place of synapse in the course of descending impulses from the tectum to lower centers through the tract under discussion and then by way of the tractus geniculatus descendens. This relation maintains in forms other than reptilian, and the 
gradual reduction of the tract phylogenetically is associated with the disappearance of the pars ventralis of the lateral geniculate nucleus in the highest mammals. From a small reptilian nucleus geniculatus pars dorsalis fibers proceed to the optic tectum which terminate in the stratum fibrosum et griseum superficiale. This afferent tectal tract anticipates the great mass of thalamo-tectal fibers which connect the dorsal part of the lateral geniculate nucleus with the tectum in higher forms, and thus represents a pathway to the tectum acquiring greater importance after the phylogenetic appearance of uncrossed optic tract fibers.

The tractus tecto-thalamicus et thalamo-tectalis dorsomedialis anterior is largely efferent with respect to the optic tectum, such efferent fibers being supplied from both the anterior and posterior tectal areas, and they are thus in relation with impulses brought into the greater part of the tectum. The distribution of cells of origin of the caudal part of this system is wide and overlaps the area of termination of the various secondary ascending tracts from lower centers including spino-mesencephalic, secondary trigeminal paths and certain fascicles of the lateral lemniscus, which in part at least must synapse with these neurons. The tract under discussion terminates in nucleus rotundus and the adjoining gray into which direct lemnisci fibers have not been followed, although there is a probability that a limited number of such fibers exist. Therefore, tractus tecto-thalamicus et thalamotectalis dorsomedialis anterior constitutes an important pathway to the dorsal thalamus for general sensibility, and as such must be recognized as of special importance in the development of this area; and it must be evident that, other things being equal, it will be large in direct proportion to the specialization of the tectum and in inverse proportion to the number of spinal and trigeminal fibers reaching the dorsal thalamus directly. A further efferent path for the tectum, supplementing the one just discussed, is the tractus tectothalamicus medialis which reaches the thalamic nucleus medialis anterior. Two tecto-thalamic paths, concerning 
which the analysis is not final, are the tractus tecto-thalamicus dorsomedialis posterior and the tractus tecto-reuniens. The former tract represents an efferent tectal system supplying the gray immediately ventral to the posterior commissure and dorsal to the caudal end of nucleus rotundus, and its adjacent gray. In certain reptiles, such as the alligator, fibers of this type have been demonstrated. However, such demonstration has not been conclusive in the other available reptilian material. The difficulties connected with the analysis of tractus tecto-reuniens have been discussed with the description of this tract.

The time is not opportune for a full discussion of the diencephalic and mesencephalic periventricular system, the richness of which is revealed only in adequate silver material. Only one feature of this system will be considered at this time and this concerns the relations of the inferior colliculus to the optic tectum. As has been emphasized elsewhere in this communication, the majority of the reptiles studied present a quadrigeminal plate, although its exact mammalian homologies are not entirely clear (pp. 59 and 60). Even in the alligator, in which the inferior colliculus is rolled into the ventricle, there is trace of an intercollicular surface sulcus. Even in those reptiles in which it occupies a superficial position it reveals its deeper origin, since its nuclear mass is a direct continuation of the optic tectal periventricular gray and it is in relation with and gives rise to fibers which enter the stratum fibrosum periventriculare of the tectum. Within the tectum such fibers come into relation with the dendrites of the cells of the periventricular layer. Other dendrites of these same cells have been shown to come into superficial relation with incoming optic fibers, thus providing a means for relating optic and auditory impulses and further providing paths to efferent centers for impulses from the inferior colliculus.

The tecto-epithalamic system, as represented by crossed and uncrossed tecto-habenular tracts, provides an anatomic basis for the correlation of somatic impulses with the various modified olfactory impulses which reach the habenula. 
The isthmo-tectal and tecto-isthmal systems mentioned in this study are in agreement with the earlier accounts in Alligator and with the presentation found in the literature dealing with these systems in amphibians, reptiles, and birds. In close relation to this system are the paths which connect the optic tectum with the cerebellum of the same and the opposite side.

Attention is directed to a set of connections designated nigro-tectal and tecto-nigral, which are related to a specialized nucleus of the entopeduncular nuclear group regarded as comparable to the substantia nigra of mammals (see also Beccari, '23).

As one may anticipate in a region so richly supplied with afferent paths, there must exist a correspondingly rich discharge system to efferent centers. Considerable numbers of these are generally recognized throughout the vertebrates and do not require further discussion here.

It is tempting in a final paragraph to speculate relative to the underlying causes of the specialization of the optic tectum as evidenced by its stratification. The raison d'être of the six fundamental strata are presented in the foregoing discussion. The causes underlying the secondary subdivision are less obvious, but it is suggested that at least for the stratum fibrosum et griseum superficiale this subdivision may be correlated with a localization of the incoming impulses, but this localization is from the surface inward, and not a regional surface localization. It has not been possible to furnish conclusive evidence for this, since this would involve tracing separately to the tectum the many fascicular components of each afferent tectal path.

For section after section, in cross and sagittal series, the cytoarchitecture of the tectum remains essentially unchanged, resembling in this respect the cerebellum, and in our opinion surface localization of the optic tectum must be sought in terms of the tectal paths to efferent centers. Moreover, an elaborate mechanism for reinforcing efferent impulses is characteristic of the optic tectum as it is of the cerebellum. 
Space has not permitted the comparison of the findings in reptiles with those obtained for other vertebrates. The writers wish especially to single out the papers of C. Judson Herrick ('17, '25) on the thalamus and tectum of Necturus and the elaborate series of communications of Castaldi, beginning in 1923, on the mesencephalon of the guinea pig.

\section{LITERATURE CITED}

ARIËNS KAPPERS, C. U. 1920 Die vergleichende Anatomie des Nervensystems. (Vol. 2 particularly.) Bohn, Haarlem.

BECCARI, N. 1923 Il centro tegmentale o interstiziale ed altre formazioni poco note nel mesencefalo e nel diencefalo di un rettile. Areh. Ital. di Anat. e Embryol., T. 20, pp. 560-619.

Bellonci, Josef 1888 Über die centrale Endigung des Nervus opticus bei den Vertebraten. Zeitschr. f. wissenschaftliche Zool., Bd. 47, S. 1-46.

Carrney, J. 1926 A general survey of the forebrain of Sphenodon punetatum. J. Comp. Neur., vol. 42, pp. 255-348.

CASTAIDI, L. 1923 Studî sulla struttura e sullo sviluppo del mesencefalo. Ricerche in Cavia Cobaya. Areh. Ital. di Anat. e Embryol., T. 20, pp. 23-225.

1924 Idem., T. 21, pp. 172-263.

1926 Idem., T. 23, pp. 481-609. 1928 Idem., T. 25, pp. 157-306.

DURWARd, A. 1930 The cell masses in the forebrain of Sphenedon punctatum. Eng. J. of Anat, vol. 65, pp. 8-44.

EDINGER, L. 1899 Untersuchungen über die vergleichende Anatomie des Gehirns. IV. Studien über das Zwisehenhirn der Reptilien. Frankfurt a. M. 1908 Vorlesungen über den Bau der nervösen Zentralorgane des Menschen und der Tiere. Siebente Auflage, Bd. 2. Leipzig.

Frederikse, A. 1931 The lizard's brain. An investigation on the histological structure of the brain of Lacerta vivipara. Callenbach, Nijkerk, Holland.

Grsi, J. 1907 Das Gehirn von Hatteria punctata. Zool. Jahrb., Anat. Abt., Bd. 25, S. 71-234.

Gross 1903 Die Sehnnervenkreuzung bei Reptilien. Zool. Jahrb., Anat. u. Ontog. Reviewed in Zool. Centralbl. for 1903, Bd. 10, S. 869-870.

HERRICK, C. J. 1917 The internal structure of the midbrain and thalamus of Necturus. J. Comp. Neur., vol. 28, pp. 215-348.

1925 The amphibian forebrain. III. The optic tracts and centers of Amblystoma and the frog. J. Comp. Neur., vol. 39, pp. 433-489.

Herrick, C. L. 1891 Contributions to the comparative morphology of the central nervous system. II. Topography and histology of the brains of certain reptiles. J. Comp. Neur., vol. 1, pp. 5-37.

1893 Contributions to the comparative morphology of the central nervous system (continued). II. Topography and histology of the brains of certain reptiles. J. Comp. Neur., vol. 3, pp. 77-106. 
Huber, G. Card, and E. C. Crosby 1926 On thalamic and tectal nuclei and fiber paths in the brain of the American alligator. J. Comp. Neur., vol. 40 , pp. $97-227$.

J ANSEN, J. 1929 A note on the optic tract in teleosts. (Reprinted from Proceedings) Koninklijke Akademie van Wetensehappen te Ansterdam, vol. 32 , no. 8 , pp. 1105-1117.

DE LANGE 1913 Das Zwischenhirn und das Mittelhirn der Reptilien. Folia Neurobiologica, vol. 7, pp. 67-138.

Larsell, O. 1924 The nucleus isthmi of the frog. J. Comp. Neur., vol. 36, pp. 309-322.

1926 The cerebellum of reptiles, lizards, and snakes. J. Comp. Neur., vol. 41, pp. 59-94.

RABL-RüCKHARD, H. 1894 Einiges über das Gehirn der Riesenschlangen. Zeitschr. f. wissenschaftliche Zool., Bd. 58, S. 694-717.

Ranón, P. 1896 Estructura del encéfalo del camaleón. Revista trimestral micrográfica, vol. 1, pp. 46-82.

RaMón Y CAJAL, S. 1911 Histologie du système nerveux, T. 2, pp. 212-215. Paris, Maloine.

RrocH, D. McK. 1929 Studies on the diencephalon of Carnivora. II. Certain nuclear configurations and fiber connections of the subthalamus and midbrain of the dog and cat. J. Comp. Neur., vol. 49, pp. 121-153.

Shanklin, W. M. 1930 The central nervous system of Chameleon vulgaris. Acta Zool., Bd. XI, S. 425-490.

Stieda, Ludwig 1875 Ueber den Bau des centralen Nervensystems der Amphibian und Reptilien. Ueber den Bau des centralen Nervensystem der Schildkröte. Leipzig.

TsaI, C. 1925 The descending tracts of the thalamus and midbrain of the opossum, Didelphis virginiana. J. Comp. Neur., vol. 39, pp. 217-248.

WARNER, Fr. J. 1931 The cell mass in the telencephalon and diencephalon of the rattlesnake, Crotalus atrox. (Reprinted from Proceedings) Konïnklijke Akadamie van Wetenschappen te Amsterdam, vol. 34, no. 8, pp. 1156-1163.

van Valkenburg, C. T. 1911 Zur vergleichenden Anatomie des mesencephalen Trigeminusanteils. Folia Neurobiologica, Bd. 5, S. 360-418.

WhINBERG, ERnst 1928 The mesencephalic root of the fifth nerve. A comparative anatomical study. J. Comp. Neur., vol. 46, pp. 249-405. 


\section{ABBREVIATIONS}

$b \because$ tec, brachium tecti medialis

cer., cerebellum

ch.opt., chiasma opticum

col.inf., colliculus inferior

com.cer., commissura cerebelli

com.col.sup., commissura colliculi superioris

com.hab., commissura habenularum

com.post., commissura posterior

com.post.p.dor., commissura posterior pars dorsalis

com.post.p.vent., commissura posterior pars ventralis

com.tecdien., commissura tecti diencephali

dec.supraopt.dor, decussatio supraoptica dorsalis

dec.supraopt.vent., decussatio supraoptica ventralis

dec.supraopt.vent.p.dor., decussatio supraoptica ventralis pars dorsalis

dec.supraopt.vent.p.vent, deeussatio supraoptica ventralis pars ventralis

dec.teg., decussatio tegmentalis

dec.teg.dor., decussatio tegmentalis dorsalis

dien.perivent.sys., diencephalic periventricular system

f.l.m., fasciculus longitudinalis medialis

fib.ans., fibrae ansulatae

hab., habenula

l.f.b., lateral forebrain bundle

l.f.b.dor.ped., lateral forebrain bundle, dorsal peduncle

l.f.b.vent.ped., lateral forebrain bundle, ventral peduncle

m.f.b., medial forebrain bundle

mes.perivent.sys., mesencephalic periventricular system

mes.r.V., mesencephalie root of the trigeminal

$N . I I I$., nervus oculomotorius

$N . I V$. , nervus trochlearis

$n . I I I$, nuclei of nervus oculomotorius

n.decsupraopt.dor., nucleus decussationis suyraopticae dorsalis

n.dor.lat.ant., nueleus dorsolateralis anterior n.dormed.ant., nucleus dorsomedialis anterior

n.gen.lat.p.dor, nucleus geniculatus lat. eralis pars dorsalis

n.gen.lat.p.vent., nucleus genieulatus lateralis pars ventralis

n.gen.pretec., nueleus genieulatus pretectalis

n.hab.lat., nucleus habenularis lateralis

n.hab.med., nucleus habenularis medialis n.isth., nucleus isthmi

n.lent.mes., nucleus lentiformis mesencephali

n.lat.prof., nucleus lateralis profundus mesencephali

n.mes.prof., nueleus mesencephalicus profundus

n.mes.r.. ., nucleus mesencephalic root of the trigeminal

n.pretect., nucleus pretectalis

n.post.dor., nucleus posterodorsalis

n.r.opt.bas., nucleus radicis opticum basalis

n.reun., nucleus reuniens

n.rot., nucleus rotundus

n.tr.tec.thal.cruc., nucleus tractus tectothalamici (et thalamo-tectalis) eruciati

r.opt.bas., radix opticum basalis

rad.M., radiation of Meynert

str.alb.cent., stratum album centrale

str.fib.perivent., stratum fibrosum periventriculare

str.fib.et gr.superf., stratum fibrosum et griseum superficiale

str.gr.cent., stratum griseum centrale

str.gr.perivent, stratum griseum periventriculare

str.med., stria medullaris

sub.nig., substantia nigra

subvent.perivent.sys., subventricular periventricular system

tec.opt., tectum opticum

tr.gen.desc, tractus geniculatus descendens

tr.gen.pretec.desc., tractus geniculatus pretectalis deseendens 
tr.hab.ped., tractus habenulo-peduncularis

tr.hab.tec., tractus habenulo-tectalis

tr.isth.tec., tractus isthmo-tectalis

tr.n.r.opt.bas.tec., tractus nuclei radicis opticum basalis ad. tectum

tr.nig.tec., tractus nigro-tectalis

tr.opt.ax.p.tec., tractus opticus axillaris pars tectalis

tr.opt.marg., tractus opticus marginalis

tr.opt.marg.p.ceph., tractus opticus marginalis pars eephalica

tr.opt.marg.p.lat., tractus opticus marginalis pars lateralis

tr.opt.marg.p.med., tractus opticus mar ginalis pars medialis

tr.rot.desc., tractus rotundi descendens

tr.str.teg.vent., tractus strio-tegmentalis ventralis

tr.str.thalintermed., tractus strio-thalamicus intermedialis

tr.tec.bulb.dor., tractus tecto-bulbaris dorsalis

tr.tec.bulb.dor.cruc., tractus tecto-bulbaris dorsalis erueiatus

tr.tec.bulb.dor.noncruc., tractus tectobulbaris dorsalis non-cruciatus

tr.tec.bulb.intermed., tractus tecto-bulbaris intermedius

tr.tec.bulb.vent., tractus tecto-bulbaris ventralis tr.tec.bulb.vent.oruc., tractus tecto-bulbaris ventralis cruciatus

tr.tec.cereb., tractus tecto-cerebellaris tr.tec.hab., tractus tecto-habenularis tr.tec.hab.cruc., tractus tecto-habenularis eruciatus

tr.tec.isth., tractus tecto-isthmalis

tr.tec.nig., tractus tecto-nigralis

tr.tec.oc., tractus tecto-oculomotorius

tr.tec.pretect., tractus tecto-pretectalis

tr.tec.reun, tractus tecto-reuniens and associated fibers

tr.tec.str., tractus tecto-striatalis

tr.tec.teg., tractus tecto-tegmentalis

tr.tec.thal.cruc., tractus tecto-thalamicus (et thalamo-tectalis) cruciatus

tr.tec.thal.dormed.ant., tractus tectothalamicus et thalamo-tectalis dorsomedialis anterior

tr.tec.thal.med., tractus tecto-thalamicus medialis

tr.tec.thal.vent.lat., tractus tecto-thalamicus et thalamo-tectalis ventrolateralis

tr.tec.thal.vent.lat.p.ant., tractus tectothalamicus et thalamo-tectalis ventrolateralis pars anterior

tr.tec.thal.vent.lat.p.intermed., tractus tecto-thalamicus et thalamo-tectalis ventrolateralis pars intermedialis $v$, ventricle

In plates $I$ to 4 , lower case letters a to $f$ designate the strata 1 to 6 , listed on pages 65 and 66 . $d^{\prime}$ (fig. $2 \mathrm{~A}$ ) marks the relation of $d$ to the inferior colliculus. 


\section{PLATES}

\section{DESCRIPTION OF PLATES}

In the drawings of the cell preparations typical fields were ehosen rather than fields which presented the most pronounced layering. 
PLATE 1

\section{EXPLANATION OF FIGURE}

1 From sagittal sections of toluidin blue preparations of the tectal region of reptiles. $A$ and $B$, Anolis carolinensis; C, Alligator mississippiensis, the + placed in the intereollicular suleus. $\times 28$. 

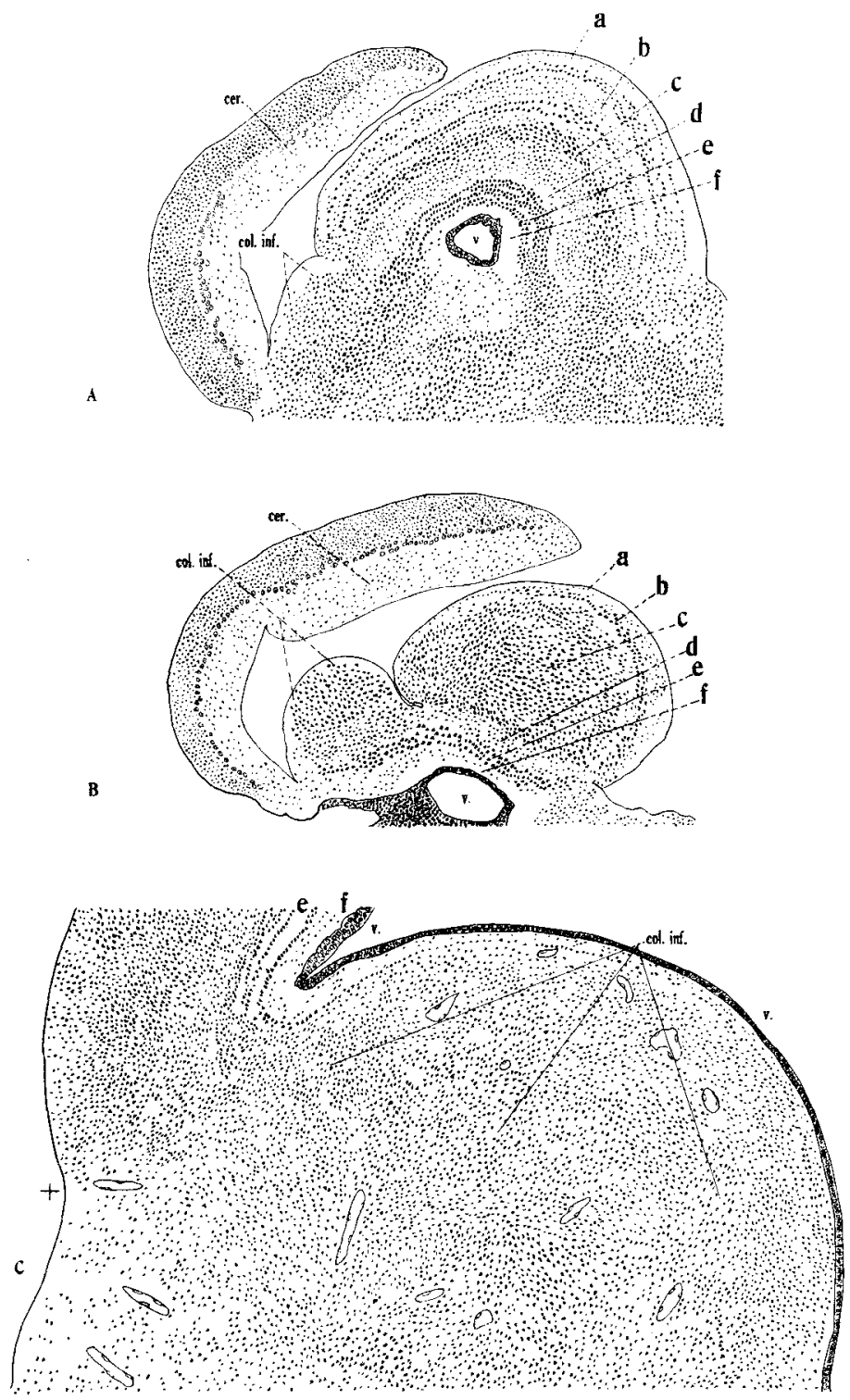
PLATE 2

EXPLANATION OF FIGURE

2 From sagittal sections of tolvidin blue preparations of the tectal region of reptiles. A, Chrysemys marginata; $B$, Thamnophis sirtalis. $\times 28$. 

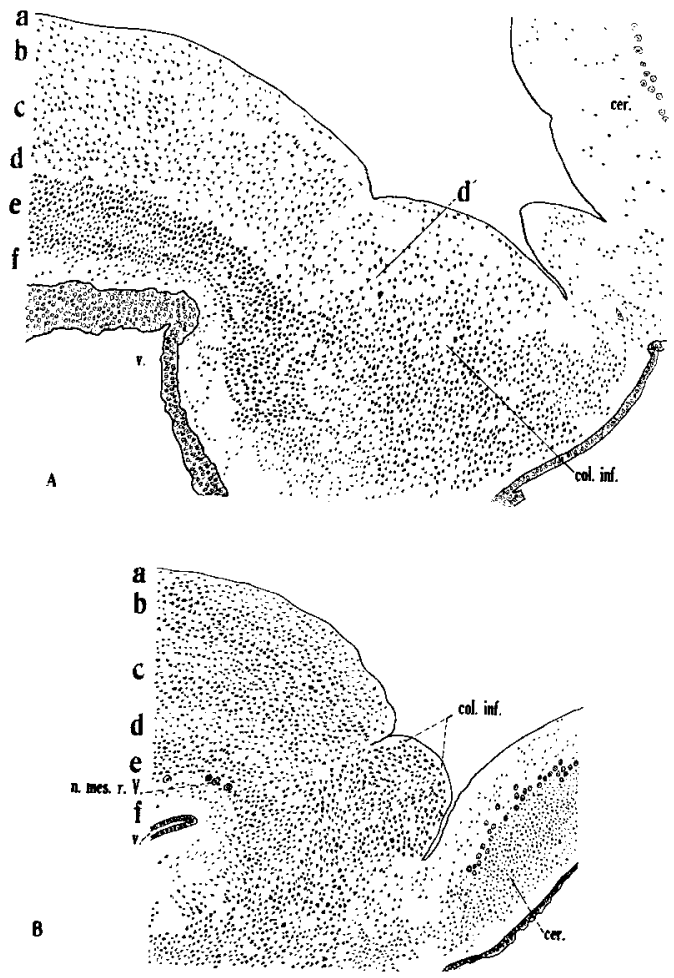


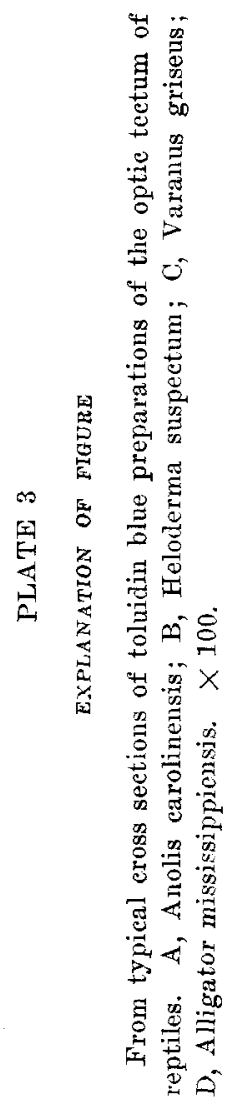

144 

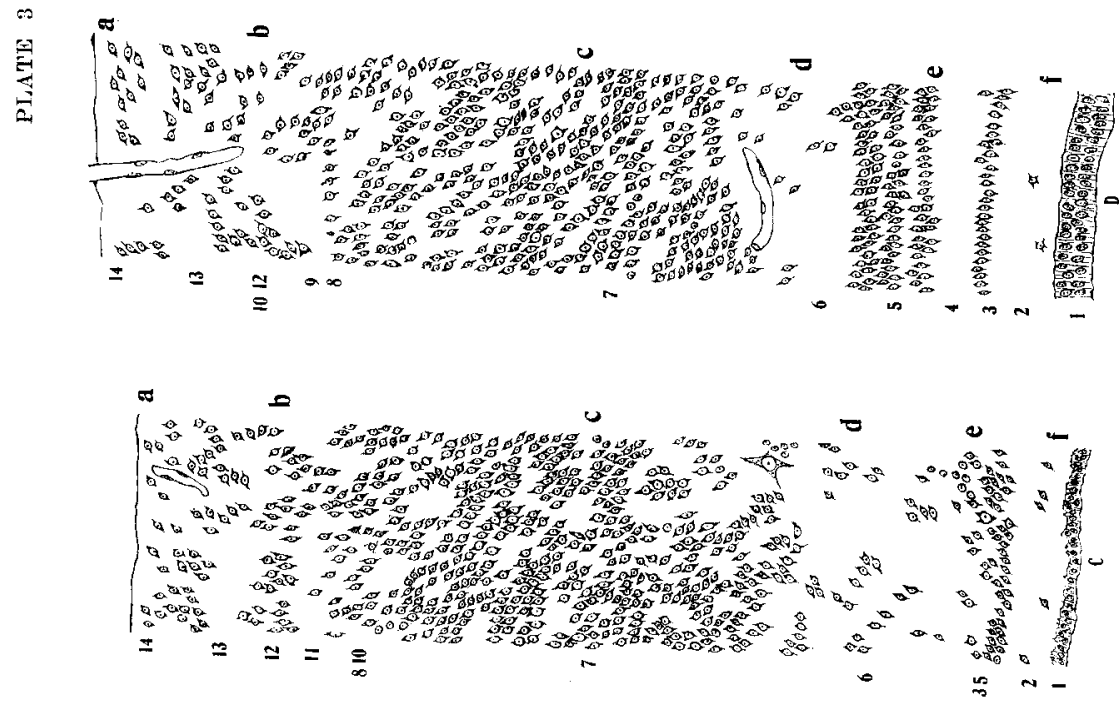

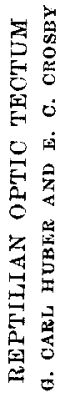
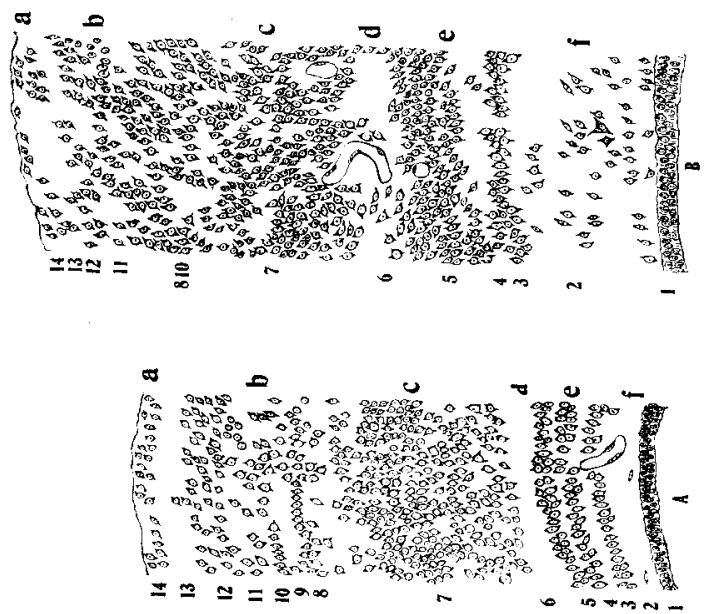


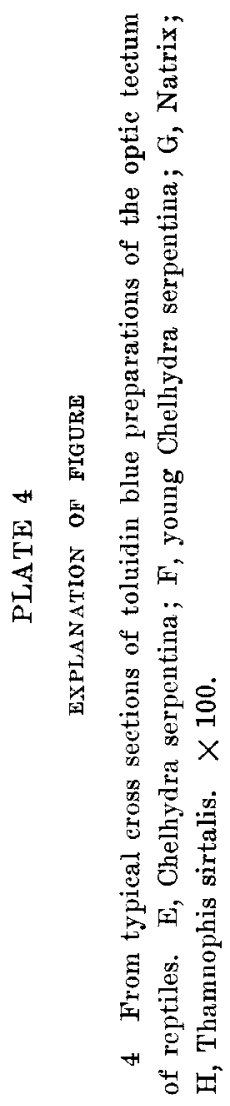



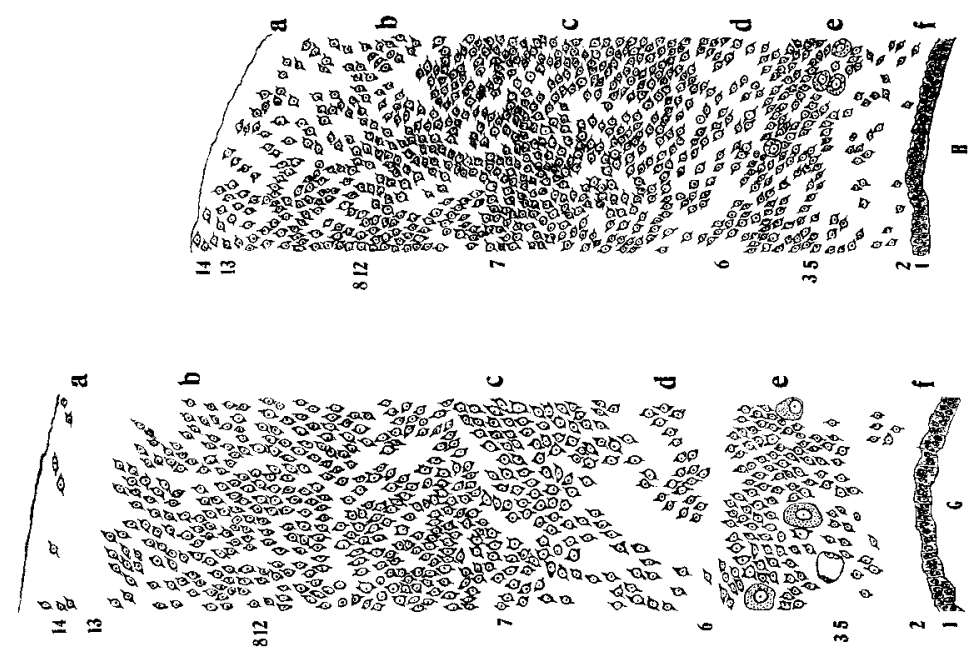

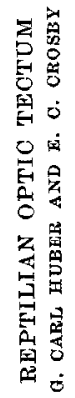
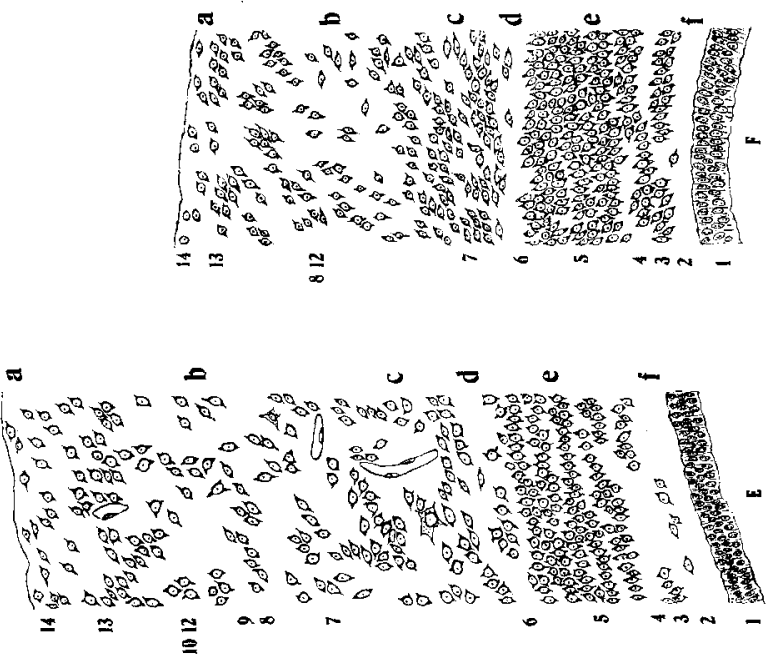
PLATE 5

\section{EXPLANATION OF FIGURE}

5 Representative, typical neurons as found in Golgi preparations of the optic tectum of Pseudoemys elegans, drawn separately with aid of camera lucida and arranged in their respective strata in a single field. (For detailed description consult pages 78 to 83 . of the text.) $\times 200$. 


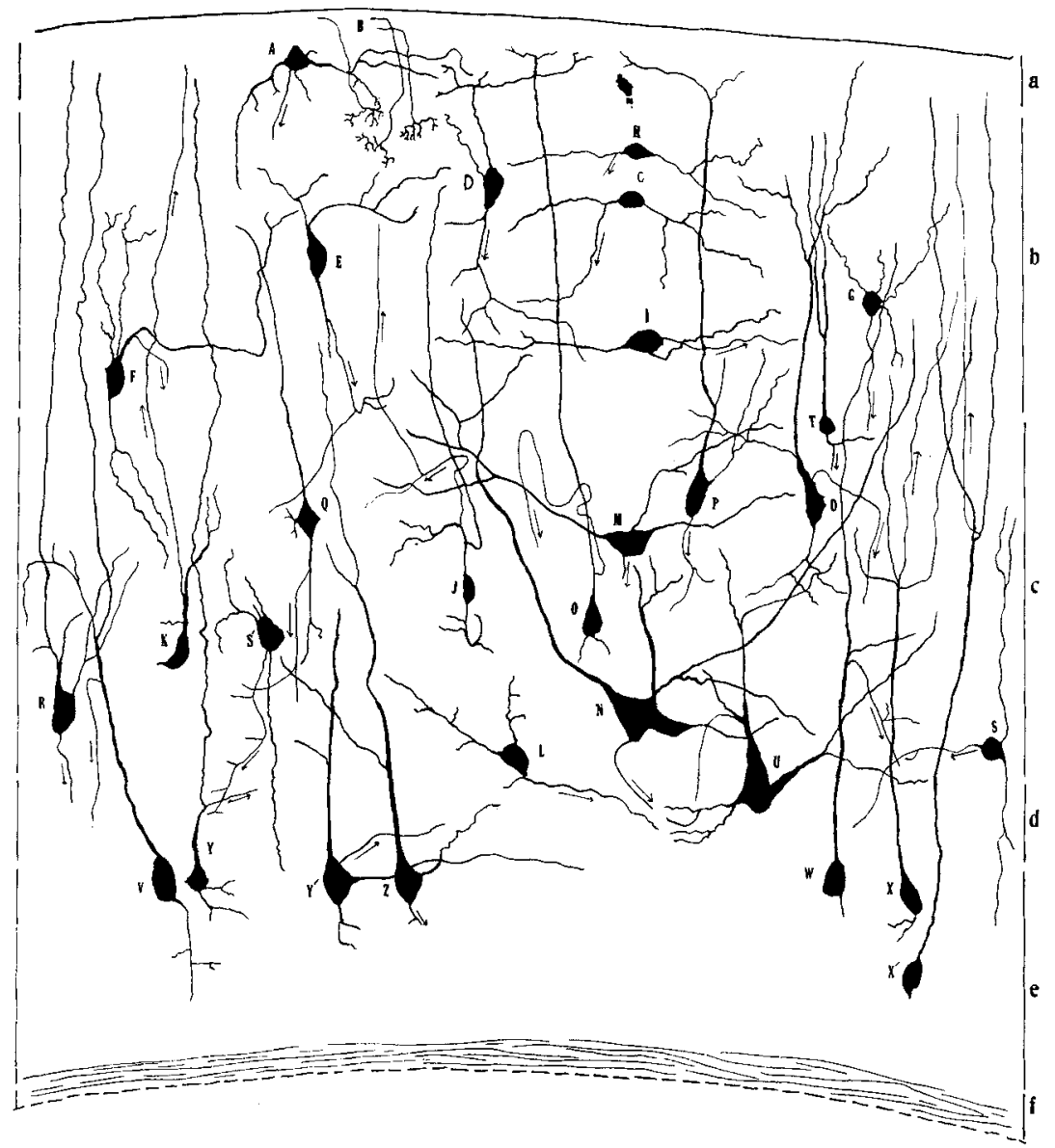


PLATE 6

\section{EXPLANATTON OF FIQURE}

6 From cross sections of pyridin silver preparations of the teetal region of reptiles. A and B, Anolis carolinensis. $\times 25$. 

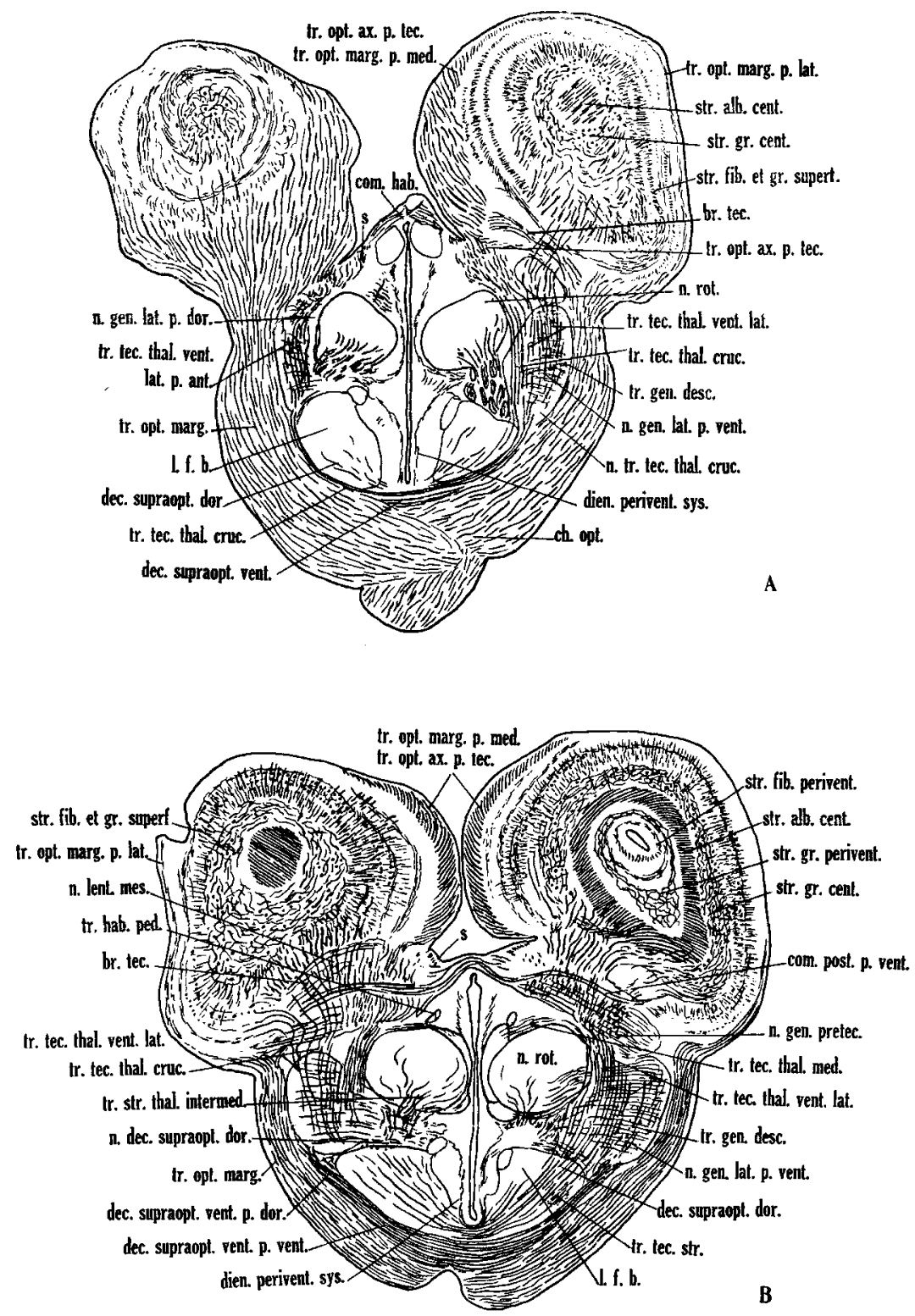


\section{PLATE 7}

\section{EXPLANATION OF FIGURE}

7 From cross sections of pyridin silver preparations of the tectal and tegmental regions of reptiles. A, Anolis carolinensis; B, Alligator mississippiensis. $\times 25$. 

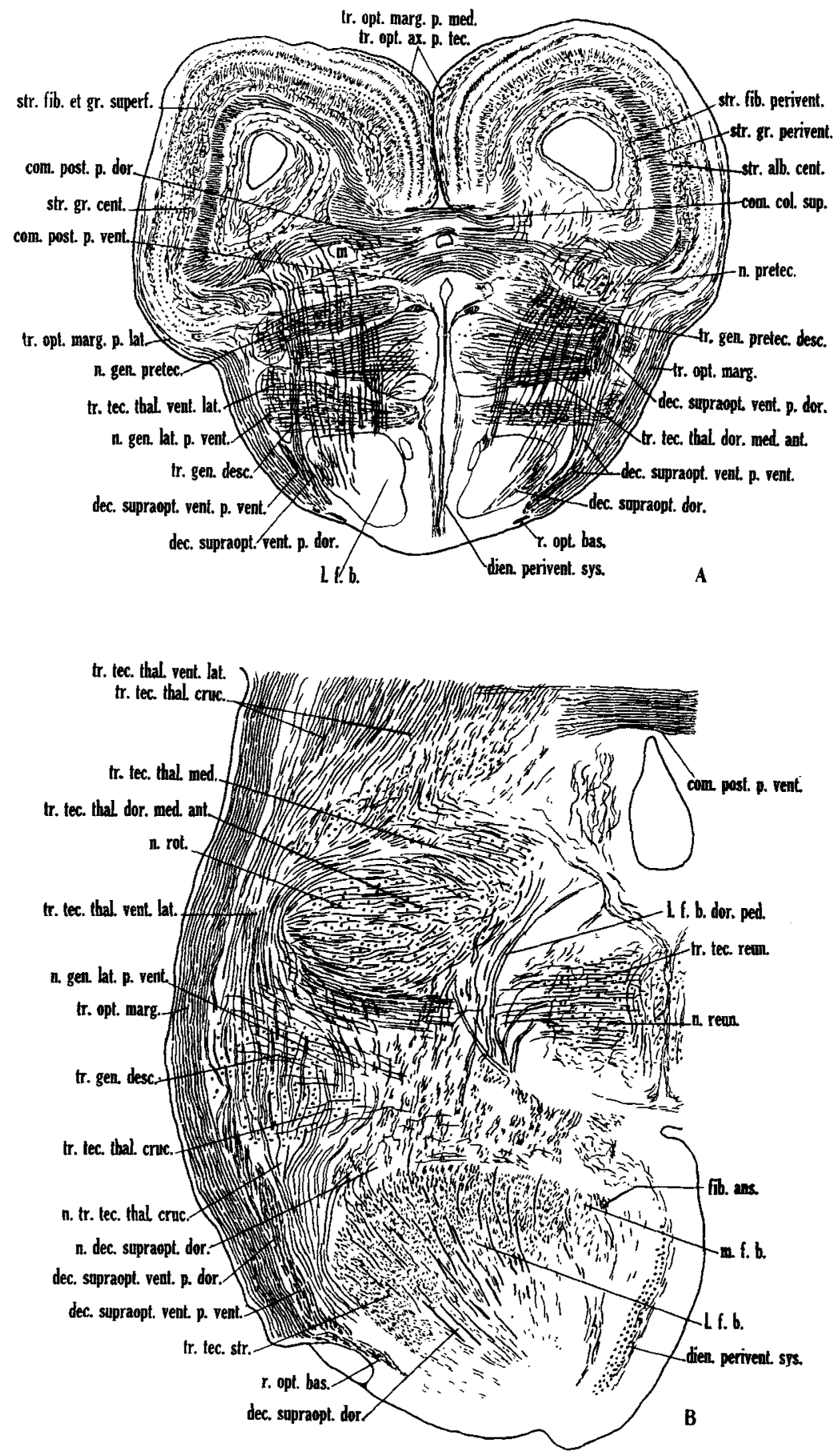

153 
PLA'T'S 8

EXPLANATION OF FIGURE

\& From cross sections of pryidin silver preparatious of the diencephalon of reptiles. A nud $\mathrm{B}$. young ('llelliyilra serpenting. $\times \mathbf{2 5}$. 

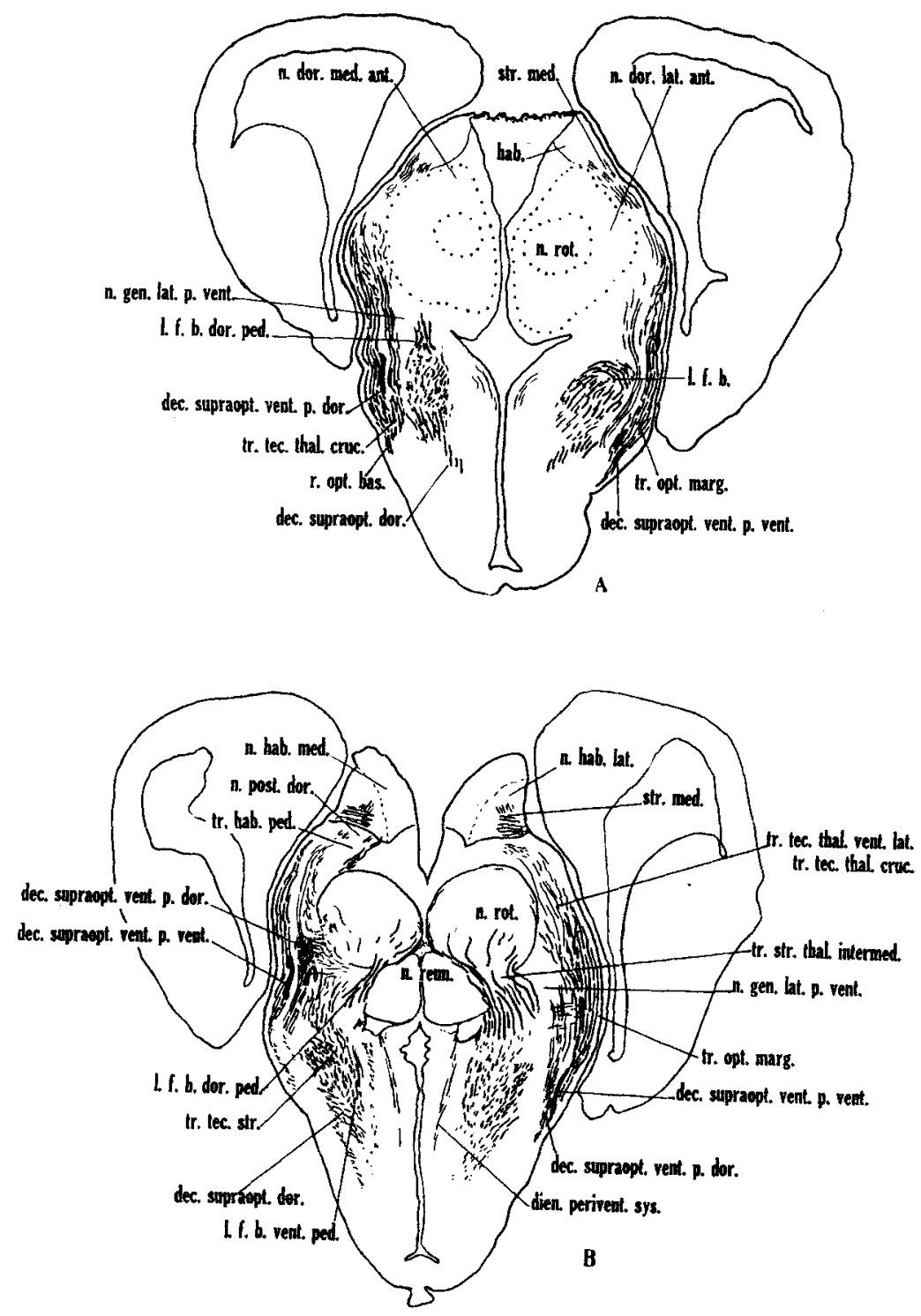
PLATE 9

EXPLANATION OF FIGURE

9 From cross sections of pyridin silver and from Weigert preparations of the tectal region of reptiles. A, pyridin silver preparation of young Chelhydra serpentina; $B$, Weigert preparation of Chrysemys marginata. $\times 25$. 
G. OARL HUBER AND E. O. CROSBY
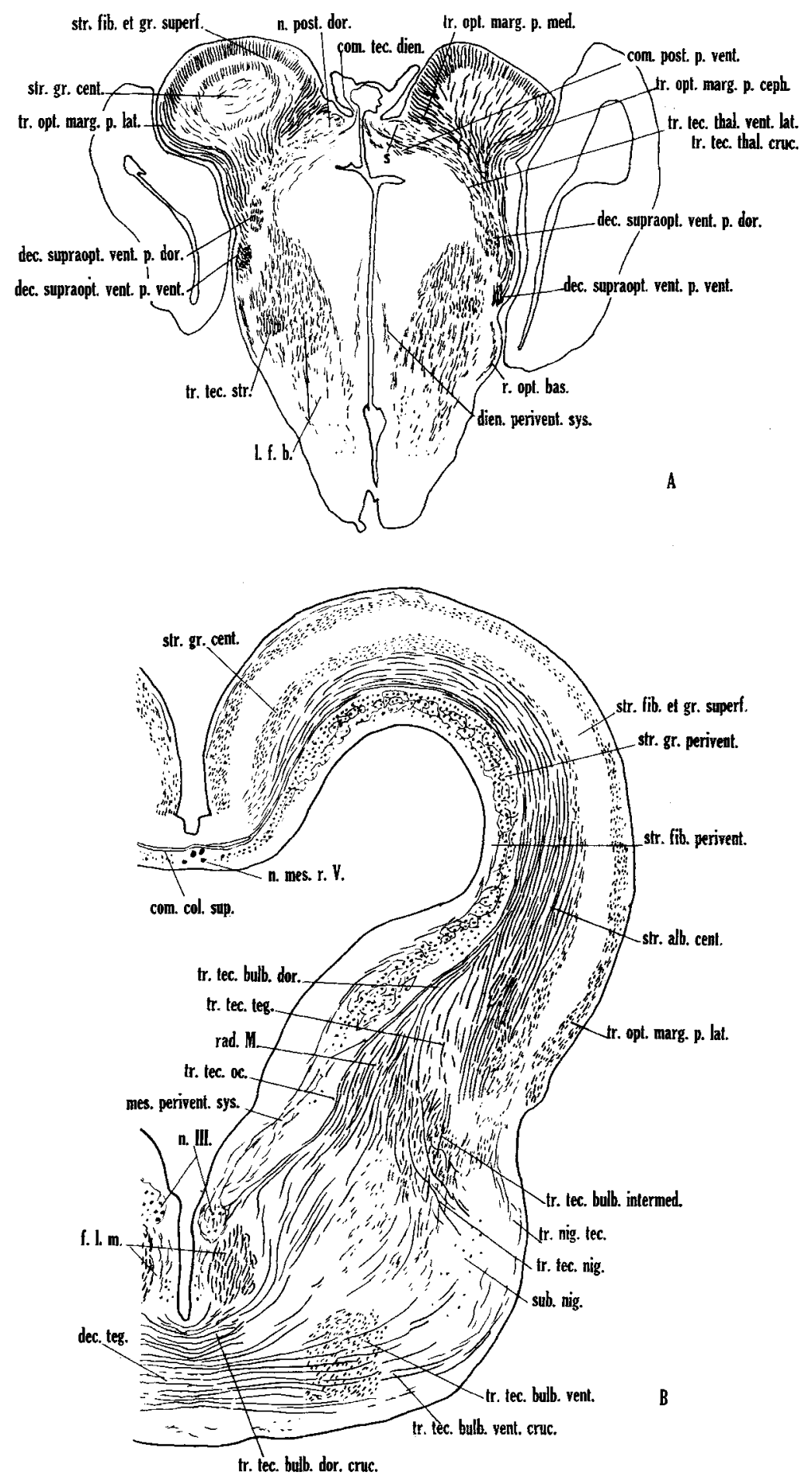
PLATE 10

EXPLANATION OF FIGURH

10 Cross sections of Weigert preparations of the tectal region of reptiles. A, Anolis carolinensis; B, Natrix. 

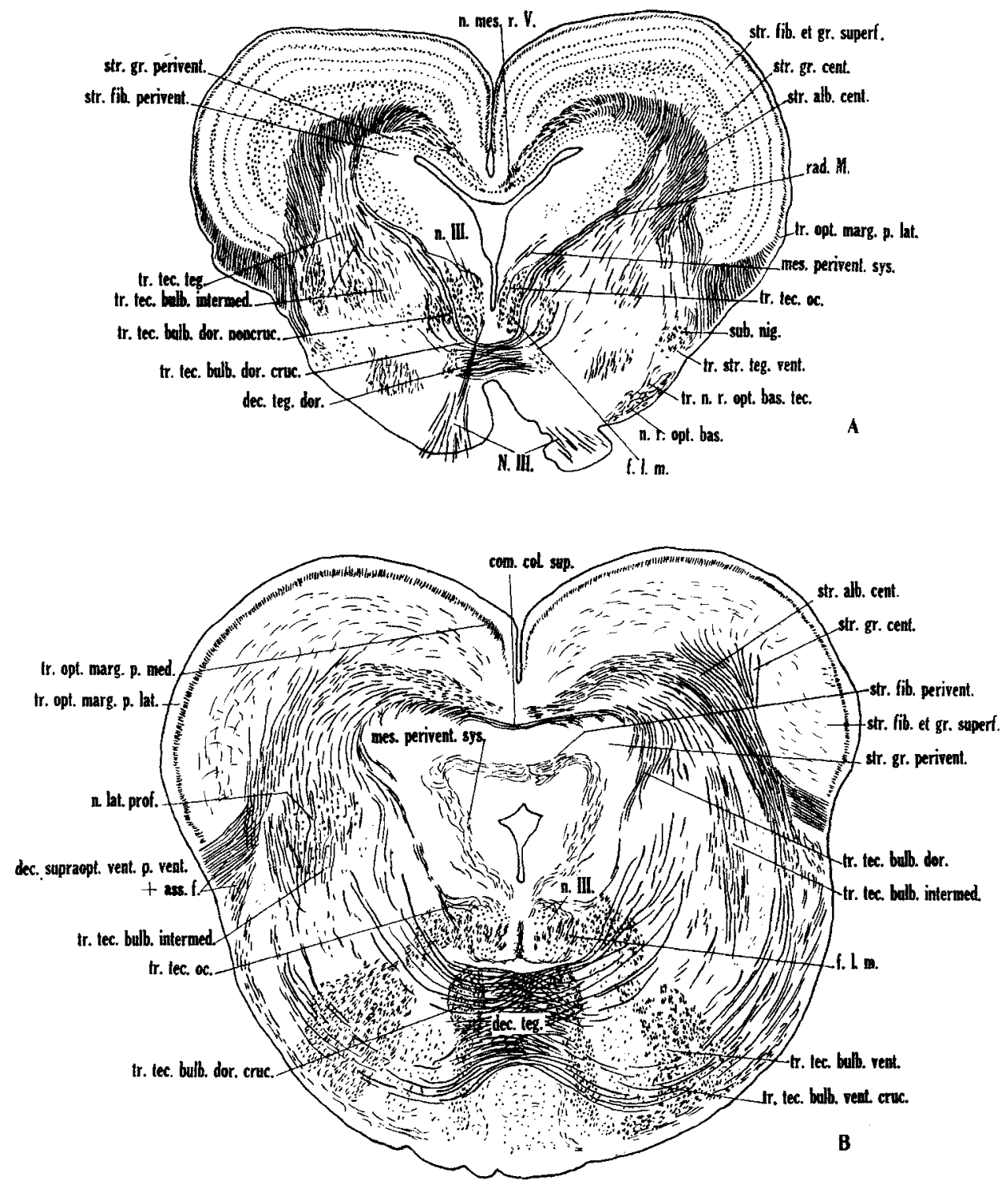
PLATE 11

\section{EXPLANATION OF FIGURE}

11 A, from sagittal sections of pyridin silver preparations of the habenular region of Natrix; B, from sagittal section of pyridin silver preparation of the habenulo-tectal region of Anolis earolinensis; C, from frontal section of Weigert preparations through the region of the nucleus rotundus of Chrysemys marginata; $D$, from sagittal section of a Weigert preparation through the region of the nucleus rotundus of Chrysemys marginata. $\times 25$. 

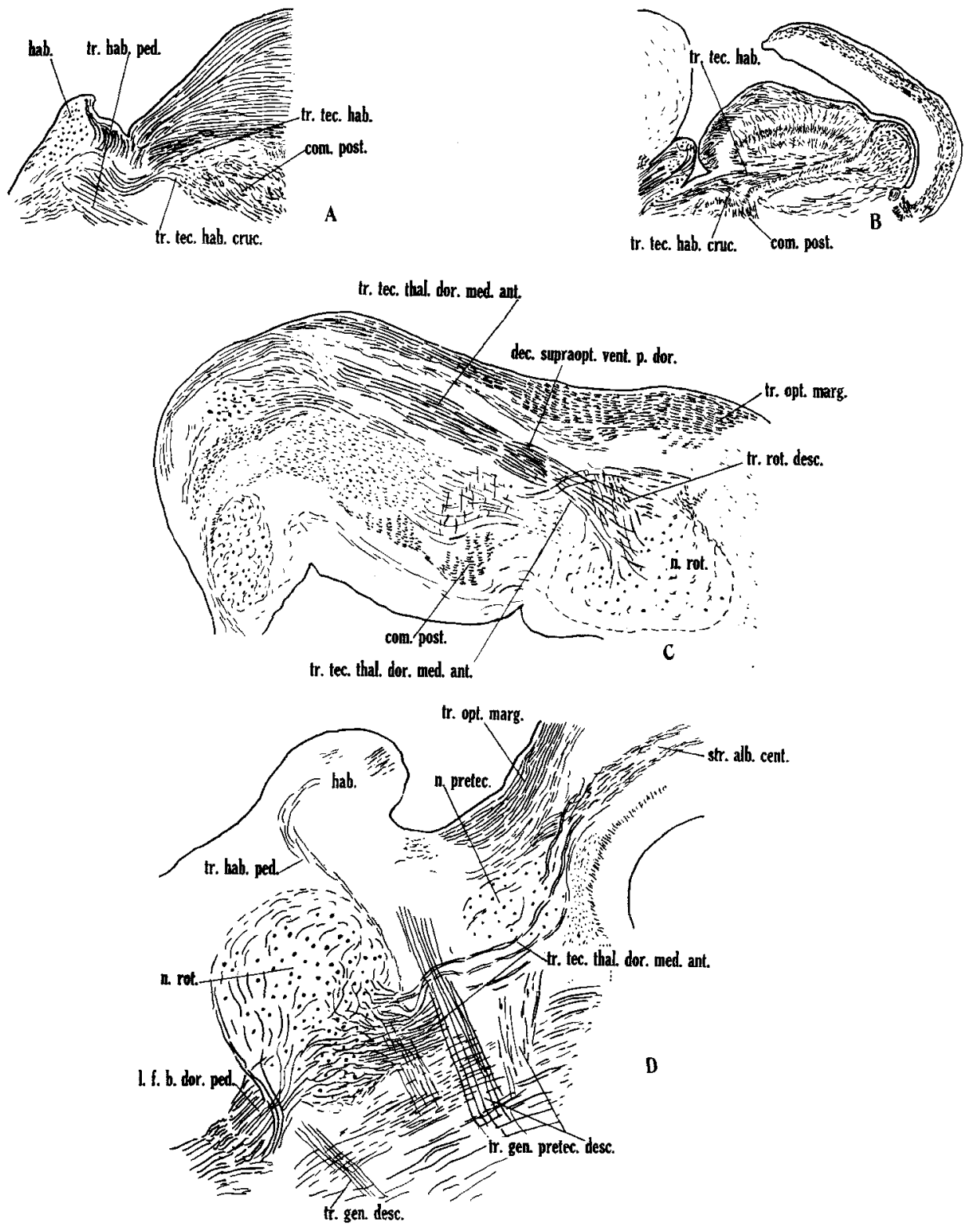


\section{PLATE 12}

EXPLANATION OF FUGURE

12 A, from a sagittal section of pyridin silver preparation of the optic tectum of Sternotherus odoratus; B, C, D, and E, from sagittal series of Weigert preparations ot the tecto-cerebellar region of Chrysemys marginata. $\times 25$. 

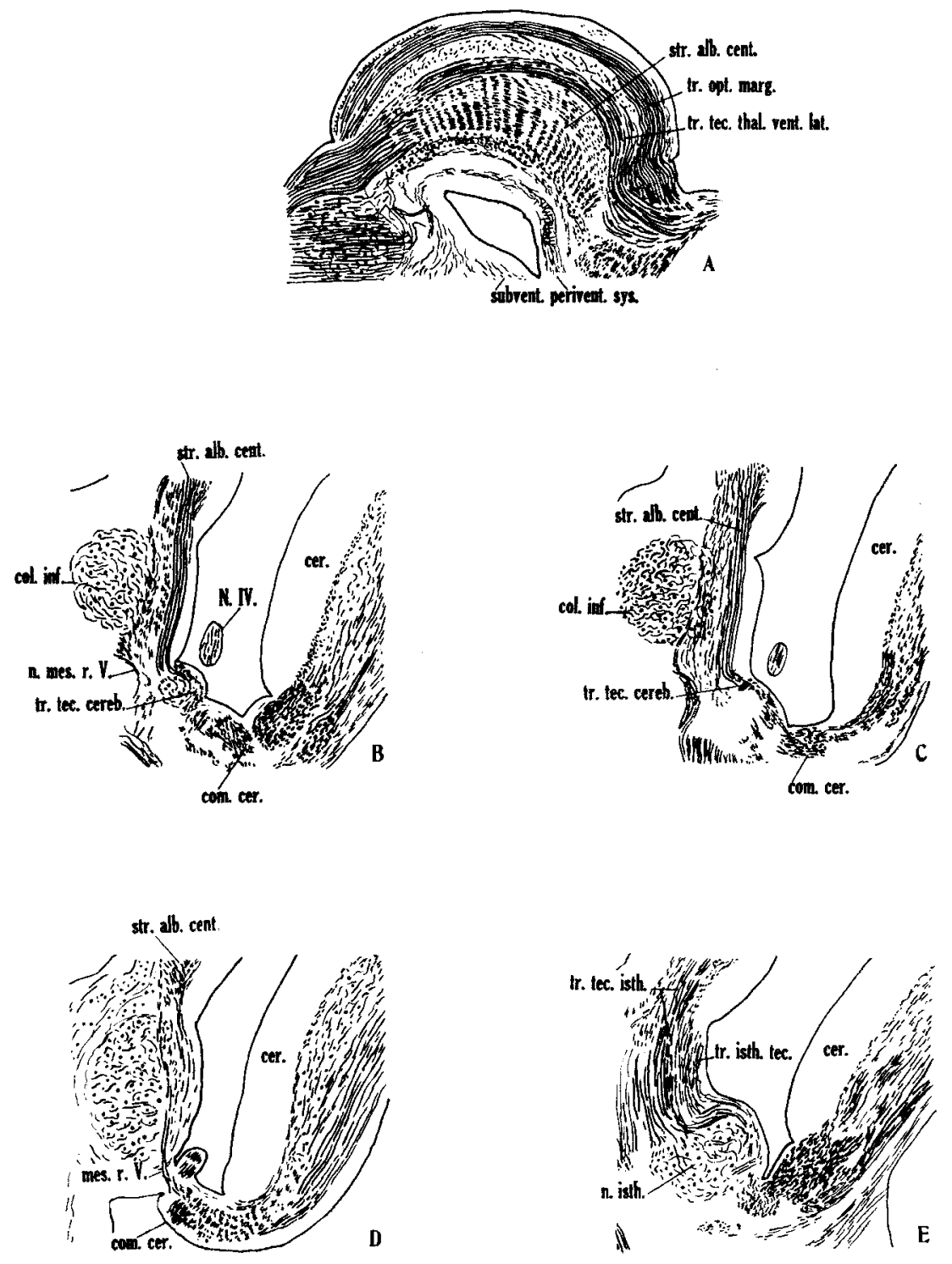